\title{
Effect of moderate electric field on structural and thermo-physical properties of sunflower protein and sodium caseinate
}

Suba, Büra Gültekin; Jahromi, Mastaneh; Casanova, Federico; Capanoglu, Esra; Ajalloueian, Fatemeh; Mohammadifar, Mohammad Amin

Published in:

Innovative Food Science and Emerging Technologies

Link to article, DOI:

10.1016/j.ifset.2020.102593

Publication date:

2021

Document Version

Peer reviewed version

Link back to DTU Orbit

Citation (APA):

Suba, B. G., Jahromi, M., Casanova, F., Capanoglu, E., Ajalloueian, F., \& Mohammadifar, M. A. (2021). Effect of moderate electric field on structural and thermo-physical properties of sunflower protein and sodium caseinate. Innovative Food Science and Emerging Technologies, 67, [102593]. https://doi.org/10.1016/j.ifset.2020.102593

\section{General rights}

Copyright and moral rights for the publications made accessible in the public portal are retained by the authors and/or other copyright owners and it is a condition of accessing publications that users recognise and abide by the legal requirements associated with these rights.

- Users may download and print one copy of any publication from the public portal for the purpose of private study or research.

- You may not further distribute the material or use it for any profit-making activity or commercial gain

- You may freely distribute the URL identifying the publication in the public portal 


\title{
Journal Pre-proof
}

Effect of moderate electric field on structural and thermo-physical properties of sunflower protein and sodium caseinate

Büşra Gültekin Subaşı, Mastaneh Jahromi, Federico Casanova, Esra Capanoglu, Fatemeh Ajalloueian, Mohammad Amin Mohammadifar

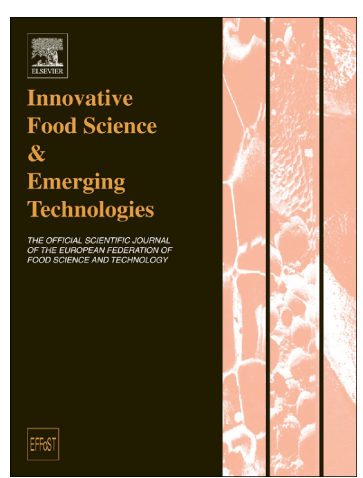

\author{
PII: $\quad$ S1466-8564(20)30539-7 \\ DOI: $\quad$ https://doi.org/10.1016/j.ifset.2020.102593 \\ Reference: $\quad$ INNFOO 102593 \\ To appear in: Innovative Food Science and Emerging Technologies \\ Received date: $\quad 16$ August 2020 \\ Revised date: $\quad 6$ December 2020 \\ Accepted date: $\quad 10$ December 2020
}

Please cite this article as: B.G. Subaşı, M. Jahromi, F. Casanova, et al., Effect of moderate electric field on structural and thermo-physical properties of sunflower protein and sodium caseinate, Innovative Food Science and Emerging Technologies (2020), https://doi.org/ 10.1016/j.ifset.2020.102593

This is a PDF file of an article that has undergone enhancements after acceptance, such as the addition of a cover page and metadata, and formatting for readability, but it is not yet the definitive version of record. This version will undergo additional copyediting, typesetting and review before it is published in its final form, but we are providing this version to give early visibility of the article. Please note that, during the production process, errors may be discovered which could affect the content, and all legal disclaimers that apply to the journal pertain.

(C) 2020 Published by Elsevier. 


\section{Effect of moderate electric field on structural and thermo-physical properties of sunflower protein and sodium caseinate}

Büşra Gültekin Subaș1 ${ }^{1,2,3}$, Mastaneh Jahromi ${ }^{2,4}$, Federico Casanova $^{2}$, Esra Capanoglu ${ }^{3}$, Fatemeh Ajalloueian $^{5}$, Mohammad Amin Mohammadifar ${ }^{2}$

${ }^{1}$ Cumhuriyet University, Hafik Kamer Ornek MYO, 58760, Sivas, Turkey.

${ }^{2}$ Food Production Engineering, National Food Institute, Technical University of Denmark, 2800, Kgs. Lyngby, Denmark.

${ }^{3}$ Food Engineering Department, Faculty of Chemical and Me alı r rgical Engineering, Istanbul Technical University, 34469, Istanbul, Turkey.

${ }^{4}$ Department of Food Science and Technology, School c ${ }^{\complement}$ Agriculture, Shiraz University, 71441-65186, Shiraz, Iran.

${ }^{5}$ Center for Intelligent Drug Delivery and Sensino Using Microcontainers and Nanomechanics (IDUN), Department of Health $\Gamma_{f} \mathrm{cl}$ nology, Technical University of Denmark, 2800, Kgs. Lyngby, Denmark.

\footnotetext{
* Corresponding author

e-mail: capanogl@itu.edu.tr

Tel: 90-212-2857340
} 


\begin{abstract}
Moderate electric field (MEF) were employed to sunflower protein isolate (SPI) and sodium caseinate (CAS) to change their structural and thermo-physical properties with a non-thermal approach. MEF treatment reduced significantly the average particle size with noticeable changes in the uniformity of SPI and CAS solutions. A maximum $10 \%$ reduction in the surface tension was observed for $0.2 \% \mathrm{w} / \mathrm{w}$ SPI sample by applying $150 \mathrm{~V}$ for 20 seconds. This effect was less pronounced for CAS samples and for the protein concentration of $2 \%$ w/w. FTIR spectra provided an increased $\alpha$-helix content for SPI inducing a bulkier, loosened and more hydrophilic structure which is unlikely for CAS. Intrinsic Fluorescence Spectroscopy revealed that MEF treatments changed the tertiary tructures of SPI and CAS. Denaturation temperatures and enthalpies of the SPI and C`S amples were decreased by MEF treatments.
\end{abstract}

Keywords: moderate electric field, sunflower proteir, s, lium caseinate, protein structure. 


\section{1. Introduction}

Food proteins are the key structural entities in food material not only for their high nutritional value, but also due to their techno-functional properties such as gelation, emulsification, and foaming (Foegeding \& Davis, 2011). Environmental concerns, sustainability and possibly high expense and potential hazards of biological diversity are the driving forces to seek and obtain alternative protein resources (Alemayehu, Bendevis, \& Jacobsen, 2015; Pojić, Mišan, \& Tiwari, 2018; Sá, Moreno, \& Carciofi, 2020). Sunflower protein is recently being investigated in terms of its functional properties as a potential alternative for commercially used proteins in food systems (u nzalez-Perez \& Vereijken, 2007; Salgado, Molina Ortiz, Petruccelli, \& Mauri, 2011). L'iliz ttion of de-oiled press cake after sunflower oil production is a promising phenomenc $>$ to obtain sustainable plant based protein (Pickardt et al., 2009; Weisz, Schneider, Scker. Comparisons for functional properties of sunflower, otein isolate (SPI) and other wellknown and versatile proteins like soy protej, egg white and/or whey protein isolates functionalities are contradictory: Some stıries teclared at least equal or better emulsification and foaming of SPI than soy protein isc' ${ }^{\prime}$ es (Albe Slabi et al., 2020; Sosulski \& Fleming, 1977). On the other hand, many studıs showed how weak the functionality of SPI than that of other protein isolates (Gonzalez-' 'e e. \& Vereijken, 2007; Pickardt et al., 2011). Different observations could be related with diferent agricultural properties of sunflower seed, type of the raw material (kernel, sec ${ }^{\wedge}$ or de-oiled press cake), presence of natural phenolic compounds as well as applı $r$ rotein extraction protocol (Albe Slabi et al., 2020; Pickardt, Eisner, Kammerer, \& $\mathrm{Ca} \cdot \mathrm{le}$, 2015). If SPI is extracted from industrial de-oiled press cake, the obtained 11S globulins ( Ielianthinin) will already be denatured due to solvent extraction followed by heat treatment during oil extraction (González-Pérez et al., 2002; Molina, Petruccelli, \& Anon, 2004). Even native and de-phenolized SPI has slight solubilities and do not form gel structures when heated (Sanchez \& Burgos, 1997). For thermal denaturation/unfolding of helianthinin, a heat treatment over $90{ }^{\circ} \mathrm{C}$ (for $\mathrm{pH} 7.0$ ) should be applied which also indicates it's thermal stability (Molina et al., 2004). SPI has the potential to be used for its functional properties but requires consistent and improved functional behaviors for ubiquitous usage or industrial upscaling.

Proteins can be modified to obtain better functional properties by using physical, chemical or enzymatic methods (Mirmoghtadaie, Shojaee Aliabadi, \& Hosseini, 2016; Molina 
et al., 2004; Shah, Umesh, \& Singhal, 2019; Sun-Waterhouse, Zhao, \& Waterhouse, 2014). Among these, physical processing methods such as microwave treatment, ohmic heating, high pressure processing, gamma irradiation, ultrasonication and pulsed electric field treatment have potential to modify varying protein types with lower costs, easy operation conditions, less time and energy consumption and no waste production when compared with chemical and enzymatic techniques (Beilen \& Li, 2002; Caruggi, Lucisano, Feyissa, Yazdi, \& Mohammadifar, 2019; Huppertz, Fox, \& Kelly, 2004; L. Jiang et al., 2014; Li, Chen, \& Mo, 2007; Malik, Sharma, \& Saini, 2017a; McKerchar et al., 2019; Messens, Van Camp, \& Huyghebaert, 1997; Mirmoghtadaie, Kadivar, \& Shahedi, 2009; Mirmoghtadaie et al., 2016; Molina et al., 2004; Shah et al., 2019; Sun-Waterhouse et al., 2014; Tapal \& Tiku, 2018; Xiong et al., 2018).

Electro-technologies like ohmic heating $(\mathrm{OH})$ as 2 pı ysical methods using electric energy as the driving force which is one of the most clean and sustainable energy sources. $\mathrm{OH}$ uses the voltages in moderate electric field (MEF) to ar $\mathrm{d}$ and homogenous heat distribution throughout the mass (Kaur \& Singh, 2016). Apr «1 1 MEF during OH treatment also performs a putative non-thermal effect on the protein structure and has a synergetic effect with the increased temperature. However, the $n \cdot \eta_{-}+$termal effect of MEF is not fully clear despite being studied over a decade. It is cor sidered that MEF has a non-thermal effect on protein's tertiary structure and effecting the cr n) rmation throughout the hydrogen and ionic bonds and hydrophobic interactions (Pereir d, Souza, Cerqueira, Teixeira, \& Vicente, 2010; Pereira, Teixeira, \& Vicente, 2011; Ro' iguts, Avelar, Vicente, Petersen, \& Pereira, 2020).

Ito et al. (2014) use $10 ; \mathrm{V} \mathrm{cm}^{-1}$ and $50 \mathrm{~Hz}$ frequency AC (alternating current) MEF application during freez $\mathrm{ng}$ f rocess to protect the freshness of purple sea urchin. In another study, induction effect , $\mathrm{f} \mathrm{AC} \mathrm{MEF} \mathrm{application}\left(667 \mathrm{~V} \mathrm{~cm}^{-1}\right.$ in amplitude and $50 \mathrm{~Hz}$ frequency) on enzymatic activity of trypsin enzyme on bovine serum albumin digestion was observed (Okumura et al., 2017). They treated $5 \mathrm{~mL}$ sample in a custom unit at $4{ }^{\circ} \mathrm{C}$ for $72 \mathrm{~h}$. Rodrigues et al. (2020), combined MEF strength $\left(10 \mathrm{~V} \mathrm{~cm}^{-1}\right.$ and $\left.20 / 50 \mathrm{MHz}\right)$ with thermal treatment $\left(20-90{ }^{\circ} \mathrm{C}\right)$ to investigate thermal unfolding of $\beta$-lactoglobulin. Bekard \& Dunstan (2014) applied oscillating MEF in a small quartz electro cell $(1 \mathrm{~cm})$ to change the tertiary structure of bovine serum albumin and lysozyme for pharmaceutical applications. They reported that the protein was unfolded when it was exposed to an electric strength $(78-500 \mathrm{~V}$ $\mathrm{cm}^{-1}$ with an oscillating frequency -sine wave- between $10-500 \mathrm{~Hz}$ during 1.5 and $3 \mathrm{~h}$, at below $25^{\circ} \mathrm{C}$ ) extremely lower than its interchain and/or intramolecular forces for long enough 
times. Non-thermal effect of MEF treatment might affect the structure of heat resistant SPI as a key for better functional properties.

In this study, we evaluate the structural, thermal and physical changes of SPI compared to CAS when exposed to non-thermal MEF application.

\section{Material and methods}

\subsection{Materials}

Crude, industrially de-oiled sunflower cake was kindly donated by Olin Edirne Oil Company (Edirne, Turkey). Cake was oven dried at $45{ }^{\circ} \mathrm{C}$ anc kept at $4{ }^{\circ} \mathrm{C}$ until the protein extraction day. The maximum storage time between storag, ani the final extraction was 2 months. Protein was isolated from the crude de-oiled cake wil ultrasound assisted isoelectric precipitation method (Subaşı et al., 2020). For phenolı compounds removal, dry cake was washed with $60 \%$ (v/v) methanol during $8 \mathrm{~h}$. Ultrası ind treatment (Branson Digital Sonifier SFX 550, St. Louis, MO, USA) at $20 \mathrm{kHz}$ (us $100 \%$ power of $550 \mathrm{~W}$ ) with a 0.5 -inch probe, at $30{ }^{\circ} \mathrm{C}$ for $10 \mathrm{~min}$ was applied to incr sasu ine extracted protein yield (Dabbour et al., 2018). The collected de-phenolized prc eir precipitates were freeze dried (Christ Beta 1-8 LSCplus, Osterode am Harz, German y) and stored at $4{ }^{\circ} \mathrm{C}$ during the experiments. The final SPI contained $87 \%(\mathrm{w} / \mathrm{w})$ crude F o $\mathrm{in}$. The characteristics of the SPI was indicated in

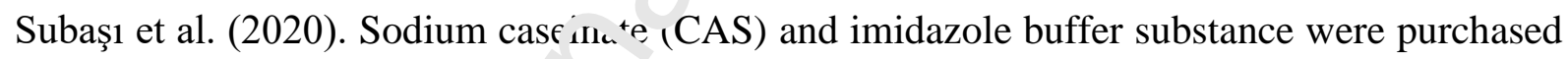
from Merck Co. (Darmstad, G rmaıy). All the other chemicals used were of analytical grade and purchased from Sigma- Aldı ih (St. Louis, MO, USA).

\subsection{MEF application}

Protein powders were dissolved in imidazole buffer $(\mathrm{pH} 7.0)$ at $2 \%(\mathrm{w} / \mathrm{w})$ and dissolved overnight on magnetic stirrer. Electric conductivities of SPI and CAS solution in buffer were $2.42 \mathrm{mS} \mathrm{cm}^{-1}$ and $2.98 \mathrm{mS} \mathrm{cm}^{-1}$, respectively at $25^{\circ} \mathrm{C}$. An insulated polyethylenepolypropylene (W500 grade) chamber with two opposing titanium electrodes was used. The adjustable gap between the electrodes, those were attached to the inner surface of the chamber, was $3.9 \mathrm{~cm}$ and the width of the cell was $9.5 \mathrm{~cm}$. The chamber has a lid made of the same insulated material with a perpendicular thermocouple attached. The maximum power supply of the equipment was $230 \mathrm{~V} \mathrm{~cm}^{-1}$ using the $60 \mathrm{~Hz}$ sine wave alternating current. The system had a screen for temperature besides equipped with a voltmeter and an amperemeter as depicted in Fig. 1. 
Application parameters were limited by the electric current transmitting capability of the equipment, except final temperature of the protein solution. Temperature of the sample was screened precisely and maximum allowed temperature was assigned as $45^{\circ} \mathrm{C}$ in order to complete the process as "non-thermal". All samples were at $25{ }^{\circ} \mathrm{C}$ prior to electric field treatments. Following this approach, the lowest and the highest applicable electro power were chosen. In this electric circuit, the protein solution was acting as the resistant element. The lowest detectable current by the amperemeter was $0.5 \mathrm{~A}$, yielding $10 \mathrm{~V} \mathrm{~cm}^{-1}$ electric field when transmitted through the protein solution. Two different application time were chosen to see the effect of treatment time. The lowest voltage long time electric field application parameters were adopted according to the study of Bekard \& Dunstan (2014). The "v1" abbreviation was nominated for "sample applied $10 \mathrm{~V} \mathrm{~cm}$ for $1 \mathrm{~h}$ ". Similarly, "v2" was nominated for "sample applied $10 \mathrm{~V} \mathrm{~cm}^{-1}$ for $2 \mathrm{~h}$ ". Th fin al temperatures of the protein solutions after treatments reached to $38{ }^{\circ} \mathrm{C}$ and $4^{5}{ }^{\circ} \mathrm{C}$, respectively. Similarly, a higher voltage with the most likely short and longer applicatı - times were determined. The shortest application time to cut off the current after swi ct.ri g on could be $5 \mathrm{sec}$. The voltage should also be applicable for the most likely long ime as well as the $5 \mathrm{sec}$ application. Some preliminary tests were performed to cho $<-$ this higher voltage considering the temperature not to exceed $45^{\circ} \mathrm{C}$. Following these - nnditions, the voltage was determined as $150 \mathrm{~V} \mathrm{~cm}^{-1}$.

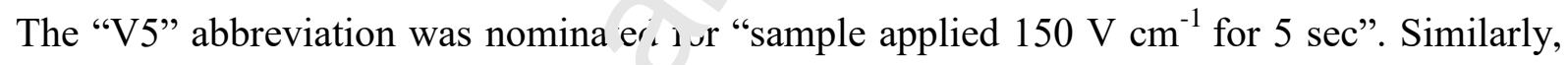
"V20" was nominated for "samr e applied $150 \mathrm{~V} \mathrm{~cm}^{-1}$ for $20 \mathrm{sec}$ ". The current, when $150 \mathrm{~V}$ $\mathrm{cm}^{-1}$ electric field was applied the protein sample was $6.7 \mathrm{~A}$. The final temperature of the protein solutions after treaı ne its reached to $30{ }^{\circ} \mathrm{C}$ and $45{ }^{\circ} \mathrm{C}$, respectively. All treated samples were immed ${ }_{1 \iota}{ }^{+} e_{1},{ }^{\prime}$ cr oled down to $25^{\circ} \mathrm{C}$ in an ice bath.

In order to elurir ate the effect of the thermal history, another sample group was prepared in the same volume, concentration and buffer. The control groups were heated to 30 ${ }^{\circ} \mathrm{C}, 38^{\circ} \mathrm{C}$ and $45^{\circ} \mathrm{C}$ using a water bath, the same temperature values with MEF treated samples reached up. They were immediately cooled down to $25^{\circ} \mathrm{C}$, in an ice bath. Particle size analysis and surface tension measurements were carried out on the control samples. No significant differences were detected (data not shown) between the native forms and control group proteins. It was assumed the heating effect until $45^{\circ} \mathrm{C}$ for denaturation/unfolding of SPI and CAS is neglectable as expected. 


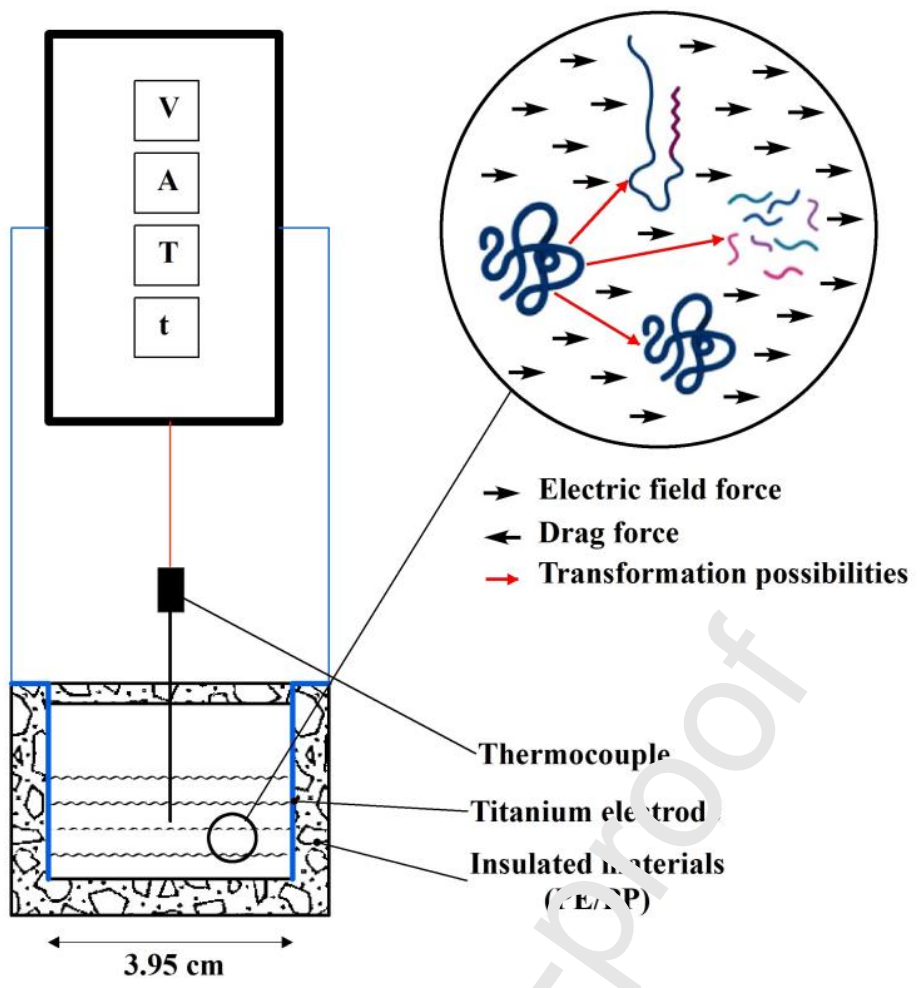

Fig. 1. Chamber of MEF treatment. $\rightarrow$ and $\leftarrow$ r $\mathrm{D}^{\prime}$ es snt the directions of electric field (action) and drag force (reaction) affecting the pr $\mu_{\mathrm{n}} \mathrm{n}^{\mathrm{articles}} \rightarrow$ is the potential change in protein particle, when exposed to electric field alı ${ }^{\top}$ drag forces. $\mathrm{V}, \mathrm{A}, \mathrm{T}$ and $\mathrm{t}$ represent voltmeter, amperemeter, temperature monitor and imer, respectively.

\subsection{Characterization of the san.}

\subsubsection{Particle size distributœ $\eta$}

Particle size tis, ribı cion and polydispersity index (PdI) were measured by via Zetasizer Nano ZS (Malv ərn Instruments, Ltd., UK). All protein samples were dissolved in imidazole buffer solution ( $\mathrm{pH} 7.0$ ) with a final protein concentration of $0.004 \%(\mathrm{w} / \mathrm{w})$. No further filtration was applied. DTS-1070 disposable folded capillary cells (Malvern Instruments, Ltd., UK) were used for measurements. Analysis were completed at $25{ }^{\circ} \mathrm{C}$ as triplicate.

\subsubsection{Interfacial tension measurements}

The interfacial tension at different concentrations was measured using a microtensiometer (Kibron EZPiplus, Helsinki, Finland) at $25^{\circ} \mathrm{C}$. The instrument was initially calibrated with deionized water. Per measurement, $3 \mathrm{~mL}$ of sample was used. The du Nouy 
method was used to determine the surface tension by the equipment. All samples were prepared at different concentrations as $0.2,0.5,1.0,1.5$ and $2.0 \%$ in imidazole buffer $(\mathrm{w} / \mathrm{w}$, $\mathrm{pH}$ 7.0). Protein solutions were dissolved overnight for the assumption of reaching thermodynamic stability. Surface tension for deionized water was recorded during calibration as $72.4 \pm 0.2 \mathrm{mN} \mathrm{m}^{-1}$ which was consistent with the literature (Adamson, 1990).

\subsubsection{Fourier Transform Infrared Spectroscopy (FTIR) spectra}

FTIR spectra was recorded in the transmission mode between the range of $4000-500$ $\mathrm{cm}^{-1}$ with a Perkin-Elmer Spectrum 100 spectrometer (Waltham, Massachusetts, USA), based on a Universal Attenuated Total Reflectance sensor 125 (''ATR-FTIR). Signals were recorded in every 4 scans and the spectra was plotted as the $\mathrm{p}$ rce itage transmittance $(\% \mathrm{~T})$ as a function of wavenumber $\left(\mathrm{cm}^{-1}\right)$.

\subsubsection{Intrinsic fluorescence spectroscopy}

Intrinsic fluorescence measurements $\mathrm{w}$ re done using the FS5 Spectrofluorometer (Edinburgh Instruments, Livingston, UK) with a $150 \mathrm{~W}$ Xenon lamp and a single photon counting photomultiplier (PMT) detecto (Famamatsu, R928P) with a voltage of $600 \mathrm{~V}$. Slit width was $2 \mathrm{~nm}$ for both excitation a. $\lambda$ emission. Samples were excited $\left(\lambda_{\text {ex }}\right)$ at $280 \mathrm{~nm}$ and the emission wavelength range was rc n 290 to $420 \mathrm{~nm}$ (with $2 \mathrm{~nm}$ measurement steps). Scan rate was $1200 \mathrm{~nm} \mathrm{~min}{ }^{-1}$. The proten. solutions were prepared at $1 \mathrm{mg} \mathrm{mL}^{-1}$ and scanned in triplicate. The spectra were ave, ngea to reduce the noise.

\subsubsection{Differential scc $n$ ^ıg c xlorimetry (DSC)}

Thermal propertics were analyzed with the TA dynamic scanning calorimeter (DSC 250, TA Instruments, New Castle, Delaware, USA). The instrument was calibrated with indium $\left(\right.$ Tpeak $=+156.5^{\circ} \mathrm{C}, \Delta \mathrm{H}_{\text {melting }}=28.5 \mathrm{~J} \mathrm{~g}^{-1}$ ) and sapphire and the cell purge was conducted with dry nitrogen $\left(50 \mathrm{~mL} \mathrm{~min}^{-1}\right)$. Roundly $3.5 \mathrm{mg}$ of samples (moisture content was around $10 \% \mathrm{w} / \mathrm{w}$ ) were sealed in hermetic aluminum pans. Another identical empty pan was used as a reference. Temperature modulation was applied from -20 to $150^{\circ} \mathrm{C}$ with $5^{\circ} \mathrm{C}$ $\min ^{-1}$ steps. No sample loss was observed. Each sample was run in triplicate. 
2.4. Statistical analysis The mean differences with \pm standard deviation (SD) were analyzed. Statistical analysis was performed using one-way analysis of variance test (ANOVA) (p < 0.05) followed by Tukey's test using the Statistical Package for the Social Science software (SPSS 22.0, SPSS Inc., Chicago, IL, USA). Data run for statistical analysis was triplicate observations.

\section{Results and discussion}

\subsection{Particle size distribution}

Protein particle size might be affected by the psical modification applications and particle size distribution depicts comprehensive inf rmc tion about heterogeneous solutions (Mirmoghtadaie et al., 2016). Size distributions of SPI and CAS as a function of intensity are presented in Table 1, and the graphs are showr in. th, supplementary file.

Native-SPI (N-SPI) dispersion sh $\mathrm{s}$ we 1 thı ee peaks and the mode of the dominant peak was $396.1 \mathrm{~nm}$ with $90.4 \%$ intensity. All $\mathrm{M}_{\mathcal{L}}\ulcorner$ treatments decreased the size of the dominant peak and also increased the numbers of $\mathrm{i}$ e smallest size particles (in a range between 8 and $22 \%$ ) within the distribution. The v2 $\mathrm{d}$ V20 produced the SPI solutions with the smallest particle size. On the other hana, higher voltages applied for short times produced more homogenous SPI mass with sn ^ller particle sizes. Lower voltage applications produced more heterogeneous solutions i. protein systems v2, V5 and V20 seemed to have some large diameter particles $\left(>4 \iota^{\urcorner}() \mathrm{Im}\right)$. This could be attributed to aggregation or partial opening of the globular structure oı SPI with the effect of MEF applications (Li et al., 2007). The size and intensity of the big aggregates (V5) decrease when extending the application time (V20). Lower voltage applications were less prone to produce bigger aggregates than higher voltage applications. Prolonged application time is correlated with induced aggregation for protein particles (Jambrak, Mason, Lelas, Paniwnyk, \& Herceg, 2014). This is correlated with the results of v1 and v2 applications.

Variance for the average hydrodynamic radius of SPI samples before and after treatments were also calculated (data not shown). All treatments reduced the hydrodynamic radius of dissolved SPI, compared with native form: $62 \%$ reduction with v1, $80 \%$ reduction with v2, 35\% reduction with V5 and 58\% reduction with V20 application was observed. 
These results were consistent with particle size distributions. Relatively less reduction of the hydrodynamic radius obtained for V5 and V20 could be due to the aggregate formation with high voltages. The tendency for aggregation of SPI was possibly due to the crosslinking of bityrosine under an excessive external force like gamma irradiation, where the size of the aggregates increased at higher doses (Malik \& Saini, 2017). The aggregates could be limiting for average particle hydrodynamic and diffusivities in the bulk solutions (Roebben et al., 2011). When considered the tendency of SPI particles for aggregation, filtration following the MEF treatment would decrease the aggregation potential during food processing.

Native-CAS (N-CAS) dispersion is characterized by three peaks with varying intensities (Table 1). The mode of the dominant peak was $34 \sim$ m with $77.2 \%$ intensity. It should be considered, N-CAS already had $\sim 4000 \mathrm{~nm}$ big par icle: with $\sim 20 \%$ intensity and a PdI value of 0.654. All applications except V20 prod ced smaller particles with higher intensities and more homogenous solutions compared to $1^{\top}$ CAS. MEF effect on whey protein also provided smaller size particles with lower PdI v. ${ }^{1} w, s$ (Rodrigues, Fasolin, et al., 2020). $150 \mathrm{~V}$ exposure for $5 \mathrm{sec}$ (V5) significantly pro u ced the smallest particle solution with the highest intensity. In their study, Wang et $a^{1}$ ( 2 v19) emphasized that casein samples had smaller particles due to the shear for e sf ultra-high pressure application however, reaggregation occurred when increa ${ }^{-d}$ the applied pressure. Similarly, prolonging the application after $5 \mathrm{sec}$, the most in er aggregations were obtained within the next $15 \mathrm{sec}$ (V20) throughout the solution. Conrequently, $150 \mathrm{~V}$ MEF treatment had a drastic effect on CAS in terms of protein partic: sizt.

Variance for an avarag hydrodynamic radius of CAS samples before and after treatments were calculat $d$ a: $35 \%$ reduction with $v 1,50 \%$ reduction with v2, 54\% reduction with V5 while 5\% incren snt with V20 (data not shown). V20 induced the protein particles to aggregate and increased the hydrodynamic radius correlated with the particle size distribution. This result was also confirmed with the MEF treated whey protein samples having the smallest hydrodynamic radius with the lower treatment periods (Pereira et al., 2016). When exposed to a shear force (electric field) and opposite reaction (drag force) the particle size of CAS decreased. Increased force broke down the casein polymers, destroyed the aggregates, however these thermodynamically unstable smaller-sized particles were prone to reaggregation (Chunyang Wang et al., 2019). To prevent the re-aggregation and obtain homogenous protein solutions with smaller size, application parameters like treatment time or voltage should be considered. 


\section{Journal Pre-proof}

\section{Table 1}

Polydispersity index (PdI) and the particle size distribution of SPI and CAS samples represented by the mode values (nm) and intensities (\%) of the peaks in the bulk. 1, 2, 3 represent the number and order of the obtained peaks.

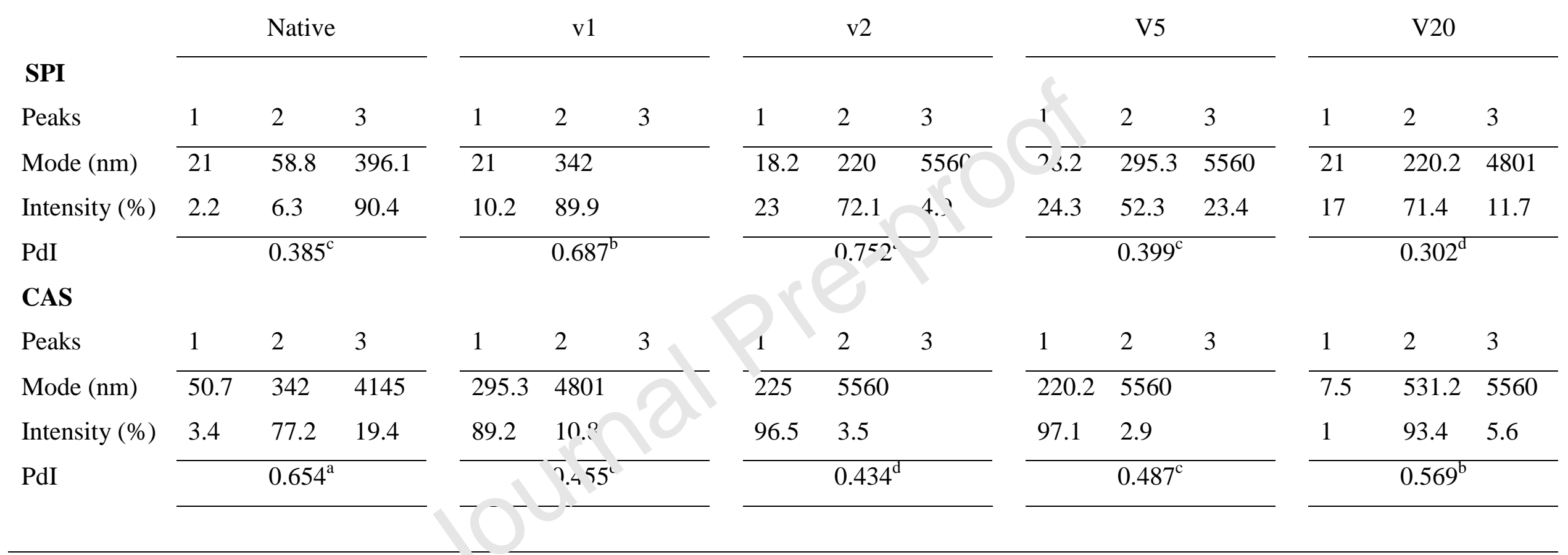

*Different letters in the same row indica $a$, lgnificant differences $(p<0.05)$. 


\subsection{Interfacial Tension}

In Table 2, the interfacial tension (IT) of native and treated SPI and CAS at $25^{\circ} \mathrm{C}$ as a function of protein concentration were provided. Dependent on the structural alteration, hydrophobic groups that buried within the protein structure would reveal and might be affected on to decrease the interfacial tension (Dickinson, 2010). Measuring the IT of the samples was considered to obtain information about the MEF effect on the surface proteins at the air/water interface. On the other hand, the protein concentration is another important variable affecting the IT of the solution until the critical surface concentration (Razumovsky \& Damodaran, 1999). The IT was observed as a function of concentration to see any trend alteration and identify the application which produces the lowist IT at the lowest protein concentration.

For SPI, all four applications significantly decreas $d$ th 2 IT of water more than SPI-N at the concentrations $0.2 \%$ and $1 \% \mathrm{w} / \mathrm{w}$. Interfacial tansinn of higher protein concentration might be lower compared with the lower concentı ${ }^{+i}$ ons due to the undesired excessive protein-protein interactions (Tomczyńska-Mlekr e al., 2018). When considered the trends of all samples, V5 had similar behavior with SP: $\mathrm{N}$ at every concentration except $0.2 \% \mathrm{w} / \mathrm{w}$. On the other hand, V20 trend provided the 'v est interfacial tension for all concentrations. SPI samples had smaller particles yieldin hydrophobicity after ultrasonic $\mathrm{X}^{\mathrm{c}}$ (Mre (Malik, Sharma, \& Saini, 2017b). These observations were also confirme 1 b; Jingh, Orsat, \& Raghavan (2013) due to the increased surface hydrophobicity couple witn higher surface area of soybean proteins after moderate electric field processing. $\Gamma$ r $\mathrm{t}$ ie concentrations higher than $1 \% \mathrm{w} / \mathrm{w}, \mathrm{v} 1$ showed a very similar trend with V20. App; rently, this is due to the concentration of $21 \mathrm{~nm}$ particles at the air/water interface. Since 2 had high amount of $18 \mathrm{~nm}$ particles, the IT was decreased up to $1 \% \mathrm{w} / \mathrm{w}$ concentration. Higher than $1 \% \mathrm{w} / \mathrm{w}$, IT increased with increased v2 concentration. Due to the fact that $1 \% \mathrm{w} / \mathrm{w}$ could be considered as the critical concentration for v 2 treated SPI. In order to detect the critical concentrations for other samples, IT as a function of broader concentration scale should be studied which is not in the scope of present study.

The lowest IT values of V20 at all concentrations were correlated with its highest homogeneity and having the smallest sized particles. However, this relation might not be applicable for every other protein solution samples and correlating the IT with PdI value may not be always straight-forward. Large protein aggregates in the protein solution with high PdI value prone to suspend or sink to the bottom and they cannot contribute to the air/water interfacial activity as much as dissolved unfolded protein particles on the surface. If a high 
PdI protein solution includes dissolved surface protein particles coupled with suspended or sink forms, a lower IT value might be obtained under non-dynamic measurement conditions. For instance, the v2 produced the lowest IT at 1\% (w/w) similar with V20 1\% (w/w) however, it had the highest PdI among all samples.

For CAS, all four application had a lower trend than CAS-N however, IT value differences were statistically significant for only $0.2,0.5$ and $1.0 \% \mathrm{w} / \mathrm{w}$ concentrations. A behavior, looks like the critical concentration value for v1 was also observed at $1 \% \mathrm{w} / \mathrm{w}$. At higher concentrations (1.5 and $2.0 \% \mathrm{w} / \mathrm{w})$ all CAS samples had similar IT at the air/water interface. Since the CAS are structurally micellar associations, they are held together mostly with ionic or hydrophobic interactions (O’Regan, Ennis, \& MLi rihill, 2009). MEF treatment would likely re-oriented these hydrophobic interactions thi hi her surface activity at the air/water interface was observed up to $1 \% \mathrm{w} / \mathrm{w}$. A $\mathrm{h}$ gुher concentrations, micellar interactions possibly increased and no more signifiran difference was observed for any application. However, MEF applications affected and a ranged the CAS for particle size and air/water interfacial activity more than ultr st and treatment (de Figueiredo Furtado, Mantovani, Consoli, Hubinger, \& da Cunha, 2 11\%). Wang et al. (2019) confirmed the relation of smaller particle size whey protein for hav ng better air/water interfacial activity after highpressure treatment. Beside these stat; - environment results, more detailed information about the non-thermal effect of MEF on p or ins surface activity could be observed with a dynamic study (Benjamins, De Feijter, Evins, ( sraham, \& Phillips, 1975).

Consequently, MEF tre: tments increased the surface activity of the dissolved SPI and CAS samples at the air/vate interface, compared with their untreated forms. Higher interfacial activity that ( btan led at relatively lower protein concentrations for both samples was also consistent with $\iota$ e literature (Tomczyńska-Mleko et al., 2018). 


\section{Table 2}

Interfacial tension $(\mathrm{mN} / \mathrm{m})$ of native and MEF treated SPI and CAS samples as a function of concentration at the air/water interface.

Protein Concentration $(\% \mathrm{w} / \mathrm{w})$

\begin{tabular}{|c|c|c|c|c|c|}
\hline Sample & 0.2 & 0.5 & 1 & 1.5 & 2 \\
\hline N-SPI & $59.68 \pm 0.9^{\mathrm{a}}$ & $55.95 \pm 0.7^{b}$ & $55.18 \pm 0.1^{\mathrm{a}}$ & $53.17 \pm 0.1^{\mathrm{c}}$ & $51.12 \pm 0.2^{\mathrm{c}}$ \\
\hline v1-SPI & $57.39 \pm 0.1^{\mathrm{c}}$ & $57.63 \pm 0.2^{\mathrm{a}}$ & $52.62 \pm 0.7^{\mathrm{c}}$ & $50.85 \pm 0.2^{\mathrm{d}}$ & $50.79 \pm 0.2^{\mathrm{cd}}$ \\
\hline v2-SPI & $58.41 \pm 0.5^{\mathrm{b}}$ & $56.53 \pm 0.1^{b}$ & $51.21 \pm 0.5^{\mathrm{d}}$ & $54.58 \pm 0.7^{\mathrm{a}}$ & $53.88 \pm 0.3^{\mathrm{a}}$ \\
\hline V5-SPI & $54.41 \pm 0.1^{\mathrm{d}}$ & $57.73 \pm 0.3^{\mathrm{a}}$ & $53.94 \pm 0.1^{b}$ & $53.72 \pm 0.1^{b}$ & $52.00 \pm 0.1^{\mathrm{b}}$ \\
\hline V20-SPI & $54.46 \pm 0.1^{\mathrm{d}}$ & $53.94 \pm 0.5^{\mathrm{c}}$ & $51.70 \pm 0.8^{\mathrm{d}}$ & 5 ร $.80 \pm 0.1^{\mathrm{d}}$ & $50.52 \pm 0.1^{\mathrm{d}}$ \\
\hline N-CAS & $54.27 \pm 0.1^{\mathrm{a}}$ & $51.98 \pm 0.1^{\mathrm{a}}$ & $51.43 \pm\left(.1^{2}\right.$ & $51.16 \pm 0.1^{\mathrm{a}}$ & $50.60 \pm 0.1^{\mathrm{a}}$ \\
\hline v1-CAS & $52.42 \pm 0.1^{b}$ & $51.35 \pm 0.2^{b}$ & $48.29 \pm v .1^{\circ}$ & $50.15 \pm 0.1^{\mathrm{b}}$ & $50.08 \pm 0.1^{\mathrm{b}}$ \\
\hline v2-CAS & $51.47 \pm 0.1^{\mathrm{c}}$ & $51.14 \pm 0.1^{\mathrm{bc}}$ & $50.7^{\circ} \pm u^{1^{b}}$ & $50.22 \pm 0.1^{\mathrm{b}}$ & $50.46 \pm 0.2^{\mathrm{ab}}$ \\
\hline V5-CAS & $51.30 \pm 0.2^{c}$ & $51.48 \pm 0.1^{\mathrm{b}}$ & $\therefore 81 \pm 0.1^{b}$ & $50.66 \pm 0.1^{\mathrm{b}}$ & $50.21 \pm 0.1^{\mathrm{ab}}$ \\
\hline V20-CAS & $51.65 \pm 0.1^{\mathrm{c}}$ & $50.72 \pm r .1^{c}$ & รง. $70 \pm 0.1^{b}$ & $50.22 \pm 0.1^{\mathrm{b}}$ & $50.30 \pm 0.1^{\mathrm{ab}}$ \\
\hline
\end{tabular}

Values are mean \pm SD. Different superscripts in $\therefore$ same column for the same protein (for SPI or CAS, individually) indicate significant differences $(\mu<0.05)$.

\subsection{Fourier Transform Infrared Spen scopy (FTIR) spectra}

FTIR spectra of SPI anc CAS were presented in Fig. 2-A and 2-B, respectively. Three amide absorption bands $10 \mathrm{I}$ V-SPI (Fig. 2-A) were observed at 1632, 1515, and $1231 \mathrm{~cm}^{-1}$, and were typically cham teristic of $\mathrm{C}=\mathrm{O}$ stretching (amide $\mathrm{I}$ ), $\mathrm{N}-\mathrm{H}$ bending (amide II), and $\mathrm{N}-\mathrm{H}$ in plane and $\mathrm{C}-\mathrm{N}$ stretching vibration (amide III), respectively. Amide I stretching and amide II shifts interpret the conformational analysis of protein's secondary structure (Das Purkayastha et al., 2016; J. Jiang, Zhang, Zhao, \& Liu, 2018). The spectra did not change for amide I band, however, intensity changes were observed at $1632 \mathrm{~cm}^{-1}$ with MEF treatments. Only V5 sample had a higher intensity than N-SPI while the lowest intensity was observed for V20. The decrease of the intensity indicates a decrease for $\beta$-sheet content and an increase for $\alpha$-helix content of the treated protein samples for SPI (Malik et al., 2017a). This was also confirmed with the amide II peak shift: The amide II peak shifted from 1515 (SPI-N) to 1521, 1522,1520 and $1530 \mathrm{~cm}^{-1}$ in the spectrum of v1, v2, V5 and V20 respectively. It means the absorption peak moved to the longer wavelength, indicating that the SPI molecules had a 
bulkier structure than N-SPI, and less energy for bending was required. The maximum and the minimum changes in this shift belong to V20 and V5, respectively. Protein's secondary structure due to unfolding is correlated with the decreasing the surface tension of water (Tomczyńska-Mleko et al., 2018). When considered the IT behavior trend of SPI samples, the lowest IT values obtained for V20, which had the maximum amide II peak shift and the highest values obtained for v5, which had the minimum amide II peak shift.

The changes of amide I and amide II bands also corresponded with the changes of $\alpha$ helix and $\beta$-sheet contents indicating the protein structure loosening (J. Jiang et al., 2018). Researchers observed a reverse situation in high intensity ultrasound and gamma irradiation SPI treatment study. After treatment, $\alpha$-helix content of the $S_{i}{ }^{\top}$ decreased, $\beta$-sheet content increased and protein structure gained a better ordered $\mathrm{f}(\mathrm{rm}$ nduced by protein-protein crosslinking (Malik \& Saini, 2018; Malik et al., 2017a . C ange in secondary structures,

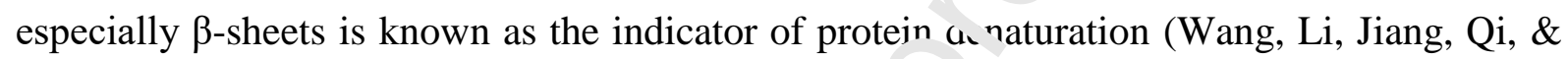
Zhou, 2014).

The FTIR spectra of N-CAS and $\mathrm{M}_{-}^{\circ}$ treated samples showed no significant difference between the samples. This indici ed no new generation of covalent bonds, as expected (J. Jiang et al., 2018). For C. S samples, the Fourier-deconvolution for amide II band was applied to see the change of protein secondary structure (Fig. 2-B). The peaks around 1624,1629 and $1638 \mathrm{~cm}^{-1}$ r or snonded to $\beta$-sheet for N-CAS. 1642 and $1655 \mathrm{~cm}^{-1}$ peaks indicated some unordered I $\omega^{-}$. mations and $\alpha$-helix structures, respectively. The peaks representing the $\beta$-sheet cor: 'nt were shifted back with MEF treatment. Moving the absorption peak to the shcter vavelength indicates the treated CAS molecules had a finer structure than N-CAS, th e $\mathrm{m}$ re energy for bending was required and the $\beta$-sheet content was increased. Similar results were obtained for whey protein under moderate electric field, the increase of $\beta$-sheet content while decrease for $\alpha$-helix alignment (Pereira et al., 2017, 2016). These results are also in correlation with smaller particle size distribution and the higher surface activities of MEF treated samples compared with N-CAS. The content of randomly coiled structures of CAS molecules decreased with MEF treatment. Moreira et al. (2019) indicated in their study about the ohmic heating effect on CAS, random coil structure might be decreased with MEF treatment and structure was rearranged. Based on the intensity changes around $1655 \mathrm{~cm}^{-1}$, $\alpha$-helix content of CAS samples decreased with MEF treatments. The max and the min decrease were obtained with V5 and V20, respectively. When considered the particle size distribution, the smallest size was obtained with V5 apparently with higher $\beta$-sheet content and the biggest size association obtained with V20 apparently 
with the highest $\alpha$-helix structures. The lower $\alpha$-helix content corresponds the higher surface hydrophobicity of for the protein (Wang et al., 2011). Higher activity at the air/water interface also confirmed this observation for MEF treated samples.

Consequently, the MEF treatments V5 and V20 mostly affected the secondary proteins structures for both SPI and CAS, however in the opposite ways. The reason for this difference is most likely the natures of the proteins; SPI, a globular 11S dominated protein and CAS, a micellar protein constituted mostly secondary structures holding together ionic/hydrophobic forces. These results are consistent with other studies in the literature; higher/increased $\alpha$ helix content of globular soybean and pea protein (with $\mathrm{pH}$ alteration) resulted with increased surface activity (Jarpa-Parra et al., 2015; Wang et al., 2011). O.1 the other hand, decreased $\alpha$ helix content for casein (with electric field treatment) and for vhey protein isolates (with phenolic interaction) were also reported (J. Jiang et al. 2618; Pereira et al., 2010). The secondary structure changes in these studies were all interpreted as the unfolding of the proteins.

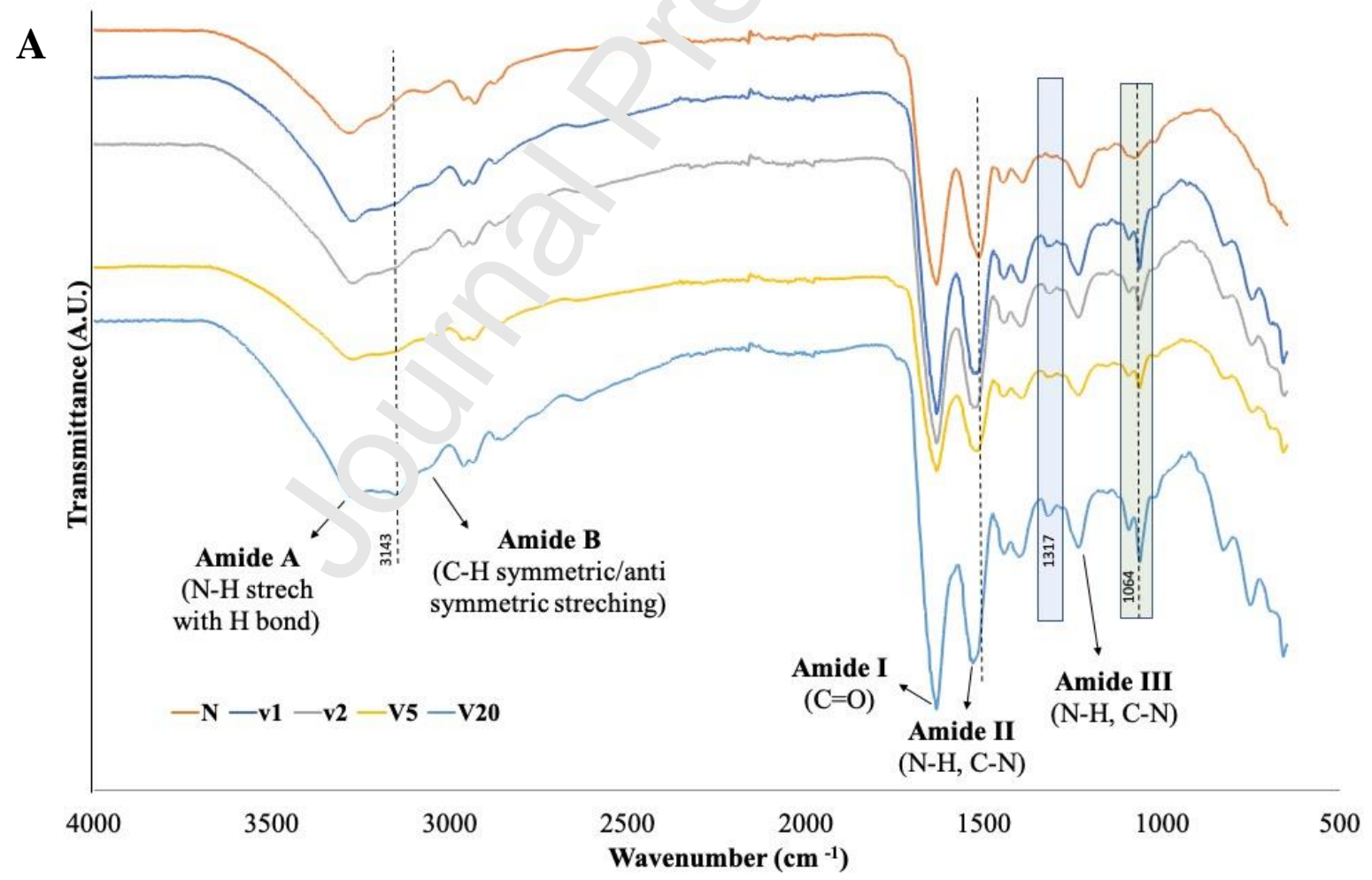




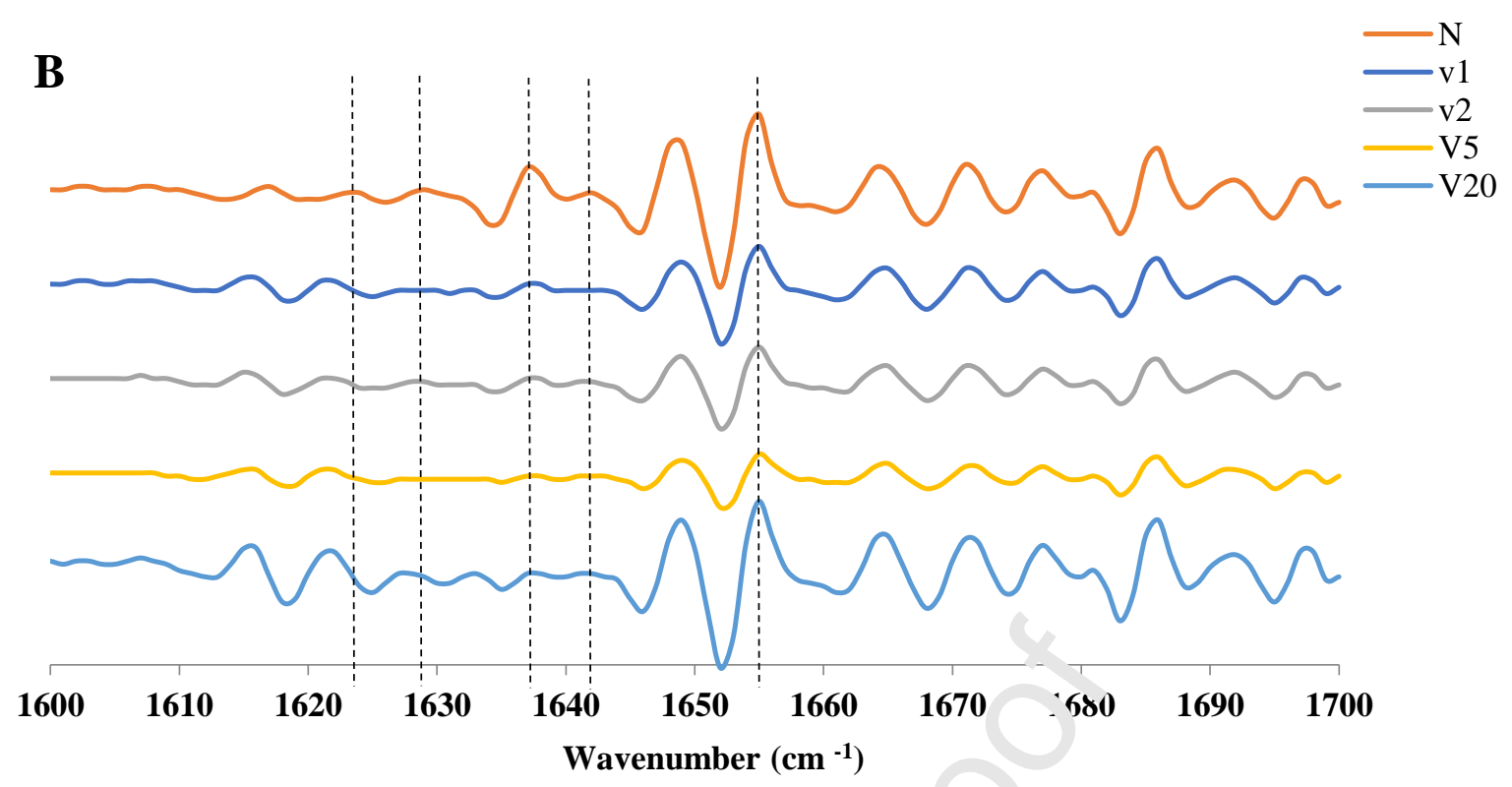

Fig. 2. FTIR spectra of SPI (A) and Fourier-deconvolutc 1 F I IR spectra of CAS (B).

\subsection{Intrinsic Fluorescence Spectroscopy}

Intrinsic fluorescence spectroscopy pre vides information about the tertiary structure of a protein (Vivian \& Callis, 2001). Emis i ${ }^{r}$. spectrum belonging to SPI samples is presented in Fig. 3-A. The recorded emission is dominated by tryptophan among all, due to its higher absorptivity and quantum yield (H $\mathrm{H}$, 2006). When compared with N-SPI, all treatments produced lower intensity of trypt,$p_{\imath} . \eta n$ emission. This indicates that tryptophan moieties were less exposed to excitation and $i$ wer emission intensities were detected. Fluorescence property of tryptophan is depender. on the polarity of its microenvironment. Tryptophan residues assigned to be buried i, hy trophobic, nonpolar zones of tertiary structure. When protein structure unfolds, tryptop han residues contact with aqueous polar media and fluorescence signals of tryptophan quench (Vivian \& Callis, 2001; Lakowicz, 2006). On the other hand, the emission maxima of all treated samples were shifted from 324 to $326 \mathrm{~nm}$ for all SPI treated samples. This red shift in the emission maxima also confirmed the increased contact of fluorophore with an increased environment polarity (J. Jiang et al., 2018). Consequently, tertiary structures of the protein isolates treated by all four applications were different than that of N-SPI. Fluorescence quenching of tryptophan could also be attributed to the conformational changes of the tertiary structure, breaking the hydrophobic bonds, aggregations and/or crosslinking of the side chains of amino acids with an outer driving force: modification applications (Chen \& Barkley, 1998; Chen, Liu, Yu, \& Barkley, 1996). With 
lower particle size distribution and higher air/water interfacial activity of MEF treated SPI samples were the confirmations of the tertiary structure alteration.

Fig. 3-B. represents the emission spectrum of CAS samples before and after MEF treatments. All treated CAS samples produced higher fluorescence intensities than N-CAS. However, only the emission maxima of v2 and V5 was shifted from 328 to $330 \mathrm{~nm}$ while no shifting was observed for v1 and V20. Red shift of emission maxima indicates the changes of tertiary structure as mentioned before. Shifting of emission maxima is dependent on the location of tryptophan within the protein molecule. If tryptophan is buried in a hydrophobic core, than the emission maxima would shift. If tryptophan is located as in contact with the environment (not buried in a hydrophobic core) or close to the 'urface, no shifting might be observed for emission maxima (Burstein, Vedenkina, \& I rkor a, 1973). Unfolded and/or partially denatured protein molecules under electrical str engt 1 exposed to drag force in the same direction of the electrical field. Hydrodynamic fric ion between the water and protein molecules promotes hydrophobic interactions to bre.k down while changing particle size, surface area and creates a novel surface (Jambra's $;$ al., 2014). Treated and partially unfolded

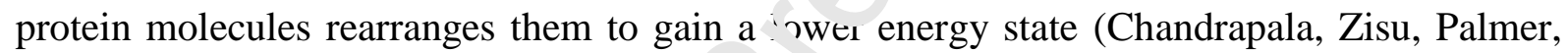
Kentish, \& Ashokkumar, 2011; Gi' 'se'en, Güzey, Bruce, \& Weiss, 2007). New hydrophobic/ionic interactions aid 'o build smaller protein pockets. Yu et al. (2014) demonstrated that aromatic ring carr es $r$ roteins buried inside the globules of $\alpha$-amylase had a novel conformation with the e fec of sonication dependent high shear. Embedding of aromatic amino acids into nove proiein pockets with conformational rearrangements explains the increment of fluorescerse in ensity. With a red shift of emission maxima and yielding the highest intensity, the $\mathrm{V} \varepsilon$ alt red the CAS conformation more than other treatment, which is also confirmed with the si condary structure results as well as having the smallest particle size distribution. Abdualrahman et al. (2016) indicated that ultrasound pretreated CAS samples produced red shift in their spectra from 350 to $354 \mathrm{~nm}$ and increased fluorescence intensity, similar to our results. Briefly, MEF treatments changed the tertiary structures and hydrophobic interactions of SPI and CAS in different ways compared with their native forms. 

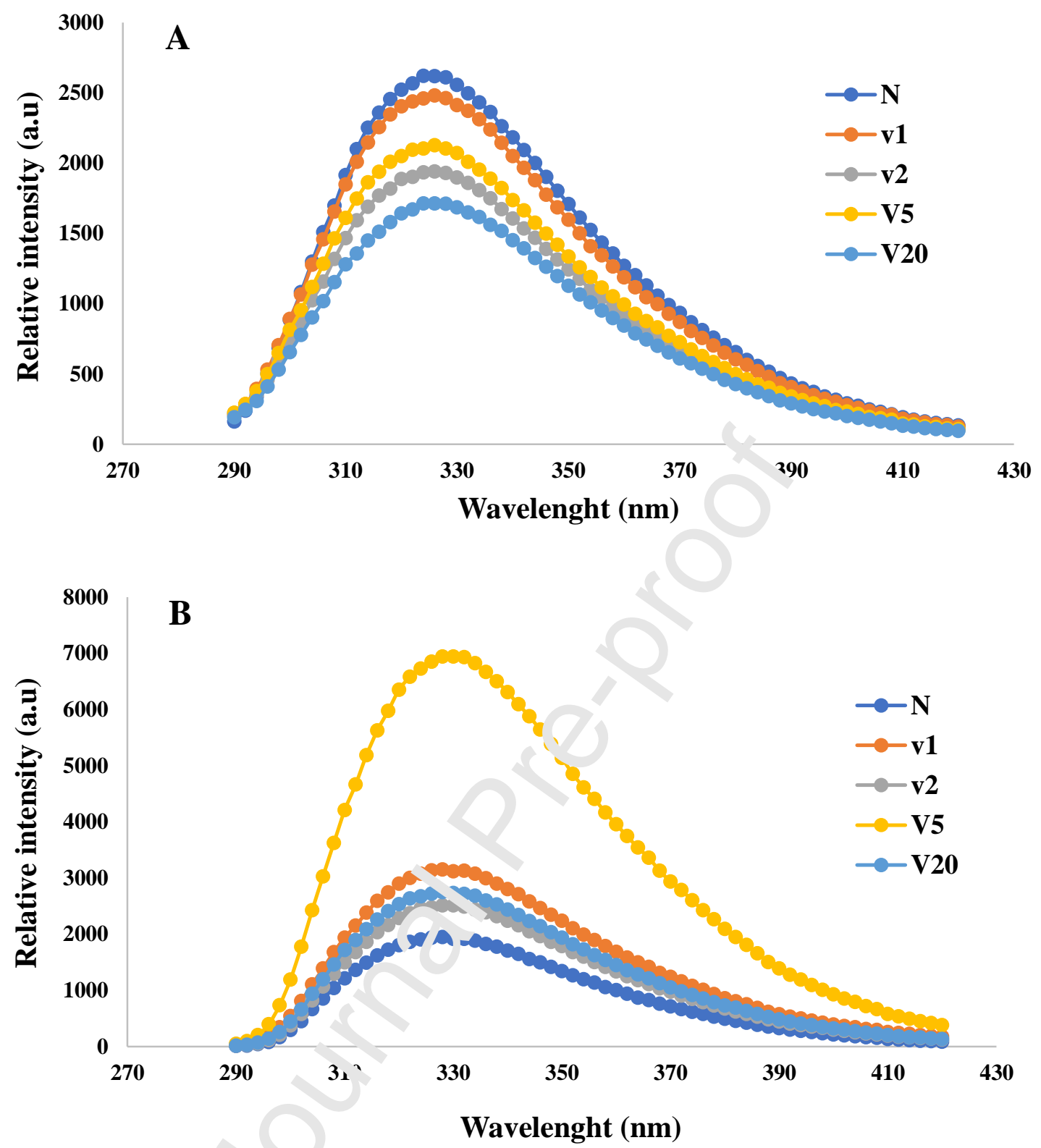

Fig. 3. Intrinsic fluoresce, ce spectra of native (N) and MEF treated SPI (A) and CAS (B)

\subsection{Differential scanning calorimetry (DSC)}

Differential scanning calorimeter (DSC) is a tool that helps to clarify protein denaturation, aggregation, folding or thermal stability phenomena (Johnson, 2013). Glass transition temperature $\left(\mathrm{T}_{\mathrm{g}}\right)$, onset temperature $\left(\mathrm{T}_{\text {onset }}\right)$, peak temperature $\left(\mathrm{T}_{\text {peak }}\right)$ and total enthalpy change $(\Delta \mathrm{H})$ are the most important thermal indicators provided by DSC (Parniakov et al., 2018). These thermal properties of native and MEF treated SPI and CAS samples are provided in Table 3.

High $\mathrm{T}_{\text {peak }}$ value is correlated with high thermal stability; furthermore, $\mathrm{T}_{\text {peak }}$ value provides information about protein tertiary structure: the more compact the tertiary 
conformation, the higher $\mathrm{T}_{\text {peak }}$ value is obtained (Tang \& Sun, 2011). There is a direct relation between the size of the particles while the relation is inverse with the PdI value: the bigger the particle size and a lower PdI, the $\mathrm{T}_{\text {peak }}$ is higher (Shiba et al., 2010). The $\Delta \mathrm{H}$ expresses the energy required to unfold protein's tertiary structure. It is related with the secondary structure of the protein system (Meng \& Ma, 2001).

Denaturation temperature $\left(\mathrm{T}_{\text {peak }}\right)$ and denaturation energy $(\Delta \mathrm{H})$ of all treated SPI samples were lower than that of N-SPI, as expected from the smaller particle sizes, secondary structure and tertiary conformational changes. Following N-SPI, the highest $\mathrm{T}_{\text {peak }}$ was observed for V5 and the lowest for the V20, similar with their structural changes. Denaturation enthalpy of all treated samples were quite lower tha: $\mathrm{N}$-SPI. Lower $\Delta \mathrm{H}$ value is also another important indicator for protein structure differe tiat on. After treating SPI with ultrasound and gamma irradiation, $\mathrm{T}_{\text {peak }}$ and $\Delta \mathrm{H}$ values ncr ased or decreased together in parallel and followed a trend depending on the +curnınt parameters as a function of conformational change (Malik, Sharma \& Saini, 2017a, v17b).

Denaturation temperature $\left(\mathrm{T}_{\text {peak }}\right)$ of CAs s a ples decreased with all MEF treatments and the lowest $\mathrm{T}_{\text {peak }}$ was obtained for $\mathrm{V} \cong$ ? The V20 was seemed to disrupt the hydrogen bonds that may exits during aggregation, tore than other applications (Tang \& Sun, 2011). This was expected due to the secondar, structure changes because the V20 exhibited the least $\beta$-sheet formation. On the other han !, d $\mathrm{k}$ uaturation energy $(\Delta \mathrm{H})$ of N-CAS was the highest as $5.17 \mathrm{~J} \mathrm{~g}^{-1}$ and it was followed $: \mathrm{v} \mathrm{VJ}$. The V5 had the highest $\beta$-sheet formation among all treated samples. However, as heing a micellar association, $\Delta \mathrm{H}$ was affected from the particle size distribution more than s." :tural conformation. The v1 was the only sample not having aggregates over $5000 \cdot m \cdot n r^{\prime}$, having a lower PdI at the same time (Shiba et al., 2010). 
Table 3. Thermal properties of native and MEF treated SPI and CAS

\begin{tabular}{cllll} 
Sample & $\mathrm{T}_{\mathrm{g}}\left({ }^{\circ} \mathrm{C}\right)$ & $\mathrm{T}_{\text {onset }}\left({ }^{\circ} \mathrm{C}\right)$ & $\mathrm{T}_{\text {peak }}\left({ }^{\circ} \mathrm{C}\right)$ & $\mathrm{DH}\left(\mathrm{J} \mathrm{g}^{-1}\right)$ \\
\hline N-SPI & $30.02 \pm 0.9^{\mathrm{c}}$ & $95.79 \pm 0.9^{\mathrm{a}}$ & $116.83 \pm 1.2^{\mathrm{a}}$ & $2.03 \pm 0.2^{\mathrm{a}}$ \\
v1-SPI & $23.82 \pm 0.4^{\mathrm{d}}$ & $90.85 \pm 0.4^{\mathrm{c}}$ & $97.64 \pm 0.9^{\mathrm{c}}$ & $0.44 \pm 0.1^{\mathrm{c}}$ \\
v2-SPI & ----- & $84.31 \pm 0.7^{\mathrm{e}}$ & $97.63 \pm 1.1^{\mathrm{c}}$ & $1.08 \pm 0.1^{\mathrm{b}}$ \\
V5-SPI & $39.01 \pm 0.1^{\mathrm{b}}$ & $94.50 \pm 0.7^{\mathrm{b}}$ & $105.61 \pm 1.4^{\mathrm{b}}$ & $0.24 \pm 0.1^{\mathrm{d}}$ \\
V20-SPI & $41.04 \pm 0.6^{\mathrm{a}}$ & $87.70 \pm 0.3^{\mathrm{d}}$ & $96.60 \pm 1.0^{\mathrm{d}}$ & $0.38 \pm 0.1^{\mathrm{cd}}$ \\
N-CAS & $48.20 \pm 0.6^{\mathrm{a}}$ & $84.15 \pm 0.6^{\mathrm{a}}$ & $103.71 \pm 0.8^{\mathrm{a}}$ & $5.17 \pm 0.6^{\mathrm{a}}$ \\
v1-CAS & $40.50 \pm 0.3^{\mathrm{c}}$ & $80.36 \pm 0.6^{\mathrm{c}}$ & $102.09 \pm 0.5^{\mathrm{b}}$ & $3.66 \pm 0.2^{\mathrm{d}}$ \\
v2-CAS & $41.04 \pm 0.8^{\mathrm{b}}$ & $80.34 \pm 0.8^{\mathrm{c}}$ & $100.34-7.6^{\mathrm{d}}$ & $4.47 \pm 0.3^{\mathrm{b}}$ \\
V5-CAS & $38.88 \pm 0.5^{\mathrm{d}}$ & $75.42 \pm 0.5^{\mathrm{d}}$ & $100.9 ? \pm 1.6^{\mathrm{c}}$ & $4.57 \pm 0.3^{\mathrm{b}}$ \\
V20-CAS & $40.43 \pm 0.2^{\mathrm{c}}$ & $82.23 \pm 0.9^{\mathrm{b}}$ & $9685=0.4^{\mathrm{e}}$ & $4.32 \pm 0.2^{\mathrm{c}}$ \\
\hline
\end{tabular}

Values are mean \pm SD. Different superscripts in an individuc colu nn for the same protein (for SPI or CAS, individually) indicate significant difference $(\mathrm{p}<0.05)$.

\section{Conclusion}

MEF affected the protein partic 'e ' ze and homogeneity, interfacial tension at the air/water interface, seconder and ter ${ }^{\text {iary }}$ structures and thermal properties of both SPI and CAS. All treatments produced lowe I rticle size SPI solutions with varying homogeneities, however, the solution with the sinaiest particle size and the highest homogeneity was obtained with V20. Similarly, the lowest stable surface tension for all measured protein concentrations was produ'ed vith V20. SPI protein's secondary and tertiary structure changed mostly with $>20$ and gained the most bulkier, flexible structure and surface hydrophilicity. The lowt t denaturation temperature was obtained also with V20 but the V5 had minimum denaturation enthalpy. Heat stable, 11S helianthinin dominated globular SPI was seemed structurally changed mostly with short time applications under $150 \mathrm{~V}$ electric field.

On the other hand, CAS was effected mostly with lower voltage $(10 \mathrm{~V})$ treatments for both $\mathrm{v} 1$ and $\mathrm{v} 2$, in terms of having the smallest particle size with the most homogenous distribution as well as the lowest surface tensions for all prepared concentrations. The v1 also produced the CAS solution that has the lowest denaturation enthalpy. Secondary structure of the CAS mostly effected from V20. The most hydrophobic structure was also obtained with V20 as well as increased particle size, possibly due to the aggregation of micelles. Breaking down the ionic/hydrophobic interactions with the effect of electrical friction possibly 
produced novel protein pockets with renovated interactions for all MEF treatments. Consequently, the non-thermal effect of MEF treatments could be proposed as a promising physical method to change the protein's structure as well as particle size and thermal properties. Structural changes like unfolding or partial denaturation of a protein considered the keys for better functional properties, therefore further investigations are required.

\section{Declaration of competing interest}

The authors declare no conflict of interest.

\section{Acknowledgements}

Authors would like to thank Dr. Hilal Yılmaz from Bi rtın University, Turkey for their technical support during intrinsic fluorescence spectrosc py ınalysis, Dr. Esben Thormann from DTU Chemistry, Denmark for surface tension na asurements and Olin Edirne Oil Company (Edirne, Turkey), for providing the de-on ${ }^{2}$ sunflower cake. This research was founded by The Scientific and Technological $\mathbf{n}$ ssearch Council of Turkey with 2214-A International Research Fellowship for PhD St. denıs.

\section{References}

Abdualrahman, M. A. Y., Ma, H., Z'10 . 1., Yagoub, A. E. G. A., Hu, J., \& Yang, X. (2016). Thermal and single frequr $\mathrm{nc}_{\text {; }}$ counter-current ultrasound pretreatments of sodium caseinate: enzymolysis inetics and thermodynamics, amino acids composition, molecular weight dist ibution and antioxidant peptides. Journal of the Science of Food and Agriculture. 96 15), 4861-4873. doi:10.1002/jsfa.7996

Adamson, A. W. (1990). The surface tension of solutions. (A. W. Adamson \& A. P. Gast, Eds.), Physical Chemistry of Surfaces (6th ed.). New York, NY: John Wiley \& Sons. doi:10.1524/zpch.1999.210.part_1.134

Albe Slabi, S., Mathe, C., Basselin, M., Framboisier, X., Ndiaye, M., Galet, O., \& Kapel, R. (2020). Multi-objective optimization of solid/liquid extraction of total sunflower proteins from cold press meal. Food Chemistry, 317(June 2019). doi:10.1016/j.foodchem.2020.126423

Alemayehu, F. R., Bendevis, M. A., \& Jacobsen, S. E. (2015). The Potential for Utilizing the Seed Crop Amaranth (Amaranthus spp.) in East Africa as an Alternative Crop to Support Food Security and Climate Change Mitigation. Journal of Agronomy and Crop Science, 201(5), 321-329. doi:10.1111/jac.12108 
Beilen, J. B. va., \& Li, Z. (2002). Enzyme technology: An overview. Current Opinion in Biotechnology, 13(4), 338-344. doi:10.1016/S0958-1669(02)00334-8

Bekard, I., \& Dunstan, D. E. (2014). Electric field induced changes in protein conformation. Soft Matter, 10(3), 431-437. doi:10.1039/c3sm52653d

Benjamins, J., De Feijter, J. A., Evans, M. T. A., Graham, D. E., \& Phillips, M. C. (1975). Dynamic and static properties of proteins adsorbed at the air/water interface. Faraday Discussions of the Chemical Society, 59, 218-229. doi:10.1039/DC9755900218

Burstein, E., Vedenkina, N., \& Ivkova, M. (1973). Tryptophan Residues in Protein Molecules. Photochemistry and Photobiology, 18, 263-279.

Caruggi, N., Lucisano, M., Feyissa, A. H., Yazdi, S. R., \& Mı'hammadifar, M. A. (2019). Effect of Ohmic Heating on the Formation and Texi Ire of Acid Milk Gels, 14(2). doi:10.1007/s11483-019-09578-y

Chandrapala, J., Zisu, B., Palmer, M., Kentish, S., \& i shokkumar, M. (2011). Effects of ultrasound on the thermal and structural characte. ${ }^{-i c t}$ cs of proteins in reconstituted whey protein concentrate. Ultrasonics Sonochemistry, 18(5), 951-957. doi:10.1016/j.ultsonch.2010.12.016

Chen, Y., \& Barkley, M. D. (1998). To sard understanding tryptophan fluorescence in proteins. Biochemistry, 37(28), S,776-9982. doi:10.1021/bi980274n

Chen, Y., Liu, B., Yu, H. T., \& Bisk v M. D. (1996). The peptide bond quenches indole fluorescence. Journal of the American Chemical Society, 118(39), 9271-9278. doi:10.1021/ja961307u

Dabbour, M., He, R., Ma. H. \& Musa, A. (2018). Optimization of ultrasound assisted extraction of prote $\mathrm{n} 1 \mathrm{om}$ sunflower meal and its physicochemical and functional properties. Journal c ${ }^{c}$ Food Process Engineering, 41(5), 1-11. doi:10.1111/jfpe.12799

Das Purkayastha, M., Borah, A. K., Saha, S., Manhar, A. K., Mandal, M., \& Mahanta, C. L. (2016). Effect of maleylation on physicochemical and functional properties of rapeseed protein isolate. Journal of Food Science and Technology, 53(4), 1784-1797. doi:10.1007/s13197-016-2197-9

de Figueiredo Furtado, G., Mantovani, R. A., Consoli, L., Hubinger, M. D., \& da Cunha, R. L. (2017). Structural and emulsifying properties of sodium caseinate and lactoferrin influenced by ultrasound process. Food Hydrocolloids, 63, 178-188. doi:10.1016/j.foodhyd.2016.08.038

Dickinson, E. (2010). Food emulsions and foams: Stabilization by particles. Current Opinion in Colloid and Interface Science, 15(1-2), 40-49. doi:10.1016/j.cocis.2009.11.001 
Foegeding, E. A., \& Davis, J. P. (2011). Food protein functionality: A comprehensive approach. Food Hydrocolloids, 25(8), 1853-1864. doi:10.1016/j.foodhyd.2011.05.008

González-Pérez, S., Merck, K. B., Vereijken, J. M., van Koningsveld, G. A., Gruppen, H., \& Voragen, A. G. J. (2002). Isolation and Characterization of Undenatured Chlorogenic Acid Free Sunflower ( Helianthus annuus ) Proteins. Journal of Agricultural and Food Chemistry, 50(6), 1713-1719. doi:10.1021/jf011245d

Gonzalez-Perez, S., \& Vereijken, J. M. (2007). Sunflower proteins: overview of their physicochemical, structural and functional properties. Journal of the Science of Food and Agriculture, 87, 2173-2191. doi:10.1002/jsfa

Gülseren, I., Güzey, D., Bruce, B. D., \& Weiss, J. (2007). Structu "al and functional changes in ultrasonicated bovine serum albumin solutions. Ultraso iics Sonochemistry, 14(2), 173183. doi:10.1016/j.ultsonch.2005.07.006

Held, P. (2006). Quantitation of Peptides and Amino Acits with a Synergy ${ }^{T M} H T$ using UV Fluorescence. BioTek Application Note.

Huppertz, T., Fox, P. F., \& Kelly, A. L. (200 ). High pressure treatment of bovine milk: Effects on casein micelles and whey prot ins. Journal of Dairy Research, 71(1), 97-106. doi:10.1017/S002202990300640X

Ito, T., Kawamura, T., Nakagawa, 4., Yamazaki, S., Syuto, B., \& Takaki, K. (2014). Preservation of fresh food us n', AC electric field. Journal of Advanced Oxidation Technologies, 17(2), 249-255. In1:10.1515/jaots-2014-0210

Jambrak, A. R., Mason, T. J. Leias, V., Paniwnyk, L., \& Herceg, Z. (2014). Effect of ultrasound treatment $\mathrm{c}^{n}$ pa icle size and molecular weight of whey proteins. Journal of Food Engineering, 21('), 15-23. doi:10.1016/j.jfoodeng.2013.08.012

Jarpa-Parra, M., Bamdad, F., Tian, Z., Zeng, H., Temelli, F., \& Chen, L. (2015). Impact of pH on molecular structure and surface properties of lentil legumin-like protein and its application as foam stabilizer. Colloids and Surfaces B: Biointerfaces, 132, 45-53. doi:10.1016/j.colsurfb.2015.04.065

Jiang, J., Zhang, Z., Zhao, J., \& Liu, Y. (2018). The effect of non-covalent interaction of chlorogenic acid with whey protein and casein on physicochemical and radicalscavenging activity of in vitro protein digests. Food Chemistry, 268, 334-341. doi:10.1016/j.foodchem.2018.06.015

Jiang, L., Wang, J., Li, Y., Wang, Z., Liang, J., Wang, R., Chen, Y., Ma, W., Qi, B., \& Zhang, M. (2014). Effects of ultrasound on the structure and physical properties of black bean protein isolates. Food Research International, 62, 595-601. 
doi:10.1016/j.foodres.2014.04.022

Johnson, C. M. (2013). Differential scanning calorimetry as a tool for protein folding and stability. Archives of Biochemistry and Biophysics, 531(1-2), 100-109. doi:10.1016/j.abb.2012.09.008

Kaur, N., \& Singh, A. K. (2016). Ohmic Heating: Concept and Applications-A Review. Critical Reviews in Food Science and Nutrition, 56(14), 2338-2351. doi:10.1080/10408398.2013.835303

Li, Y., Chen, Z., \& Mo, H. (2007). Effects of pulsed electric fields on physicochemical properties of soybean protein isolates. LWT - Food Science and Technology, 40(7), 1167-1175. doi:10.1016/j.lwt.2006.08.015

Malik, M. A., \& Saini, C. S. (2017). Gamma irradiation o. alk lli extracted protein isolate from dephenolized sunflower meal. LWT - Food Sci nce and Technology, 84, 204-211. doi:10.1016/j.lwt.2017.05.067

Malik, M. A., \& Saini, C. S. (2018). Rheological anu ctr.ctural properties of protein isolates extracted from dephenolized sunflower mf al Effect of high intensity ultrasound. Food Hydrocolloids, 81, 229-241. doi:10.1016 i.foudhyd.2018.02.052

Malik, M. A., Sharma, H. K., \& Sai i. '. S. (2017a). Effect of gamma irradiation on structural, molecular, thermal and rheological properties of sunflower protein isolate. Food Hydrocolloids, 72, 312-32. tnı:10.1016/j.foodhyd.2017.06.011

Malik, M. A., Sharma, H. K., \& Jain1, C. S. (2017b). High intensity ultrasound treatment of protein isolate extracted $\mathrm{r}: \mathrm{\text {ou }}$ uphenolized sunflower meal: Effect on physicochemical and functional roperties. Ultrasonics Sonochemistry, 39, 511-519. doi:10.1016/j.ultsor ch.'́2)17.05.026

McKerchar, H. J., Clereıs, S., Dobson, R. C. J., Dyer, J. M., Maes, E., \& Gerrard, J. A. (2019). Protein-protein crosslinking in food: Proteomic characterisation methods, consequences and applications. Trends in Food Science and Technology, 86, 217-229. doi:10.1016/j.tifs.2019.02.005

Meng, G. T., \& Ma, C. Y. (2001). Thermal properties of Phaseolus angularis (red bean) globulin. Food Chemistry, 73(4), 453-460. doi:10.1016/S0308-8146(00)00329-0

Messens, W., Van Camp, J., \& Huyghebaert, A. (1997). The use of high pressure to modify the functionality of food proteins. Trends in Food Science and Technology, 8(4), 107112. doi:10.1016/S0924-2244(97)01015-7

Mirmoghtadaie, L., Kadivar, M., \& Shahedi, M. (2009). Effects of succinylation and deamidation on functional properties of oat protein isolate. Food Chemistry, 114(1), 
127-131. doi:10.1016/j.foodchem.2008.09.025

Mirmoghtadaie, L., Shojaee Aliabadi, S., \& Hosseini, S. M. (2016). Recent approaches in physical modification of protein functionality. Food Chemistry, 199, 619-627. doi:10.1016/j.foodchem.2015.12.067

Molina, M. I., Petruccelli, S., \& Anon, M. C. (2004). Effect of pH and ionic strength modifications on thermal denaturation of the 11S Globulin of Sunflower (Helianthus annus). Journal of Agricultural and Food Chemistry, 52, 6023-6029. doi:10.1021/jf0494175

Moreira, T. C. P., Pereira, R. N., Vicente, A. A., \& da Cunha, R. L. (2019). Effect of Ohmic

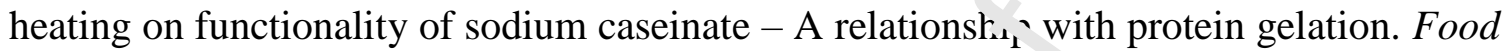
Research International, 116(April), 628-636. doi:10.1015/j.t )odres.2018.08.087

O’Regan, J., Ennis, M. P., \& Mulvihill, D. M. (2009). Mil Prı teins. In G. O. Phillips \& P. A. Williams (Eds.), Handbook of hydrocolloids (?nd ed.). Woodhead Publishing. doi:10.1016/B978-0-12-374039-7.X0001-3

Okumura, T., Yamada, K., Yaegashi, T., Tak sic shi, K., Syuto, B., \& Takaki, K. (2017). External AC electric field-induced cor+ ormational change in bovine serum albumin. IEEE Transactions on Plasma Scie. re 45(3), 489-494. doi:10.1109/TPS.2017.2657748

Parniakov, O., Bals, O., Barba, F. J., Mykhailyk, V., Lebovka, N., \& Vorobiev, E. (2018). Application of differential sc $\mathrm{nn}: \mathrm{ng}_{\mathrm{g}}$ calorimetry to estimate quality and nutritional properties of food products. Critical Reviews in Food Science and Nutrition, 58(3), 362385. doi:10.1080/104083? ?.20:6.1180502

Pereira, R. N., Rodrigues, $\mathrm{r}$ M, Altinok, E., Ramos, Ó. L., Xavier Malcata, F., Maresca, P., Ferrari, G., Teixeir ı, J. A., \& Vicente, A. A. (2017). Development of iron-rich whey protein hydrogels fo ${ }^{1}$ lowing application of ohmic heating - Effects of moderate electric fields. Food Research International, 99(January), 435-443. doi:10.1016/j.foodres.2017.05.023

Pereira, R. N., Rodrigues, R. M., Ramos, Ó. L., Xavier Malcata, F., Teixeira, J. A., \& Vicente, A. A. (2016). Production of Whey Protein-Based Aggregates Under Ohmic Heating. Food and Bioprocess Technology, 9(4), 576-587. doi:10.1007/s11947-015$1651-4$

Pereira, R. N., Souza, B. W. S., Cerqueira, M. A., Teixeira, J. A., \& Vicente, A. A. (2010). Effects of electric fields on protein unfolding and aggregation: Influence on edible films formation. Biomacromolecules, 11(11), 2912-2918. doi:10.1021/bm100681a

Pereira, R. N., Teixeira, J. A., \& Vicente, A. A. (2011). Exploring the denaturation of whey 
proteins upon application of moderate electric fields: A kinetic and thermodynamic study. Journal of Agricultural and Food Chemistry, 59(21), 11589-11597. doi:10.1021/jf201727s

Pickardt, C., Eisner, P., Kammerer, D. R., \& Carle, R. (2015). Pilot plant preparation of lightcoloured protein isolates from de-oiled sunflower (Helianthus annuus L.) press cake by mild-acidic protein extraction and polyphenol adsorption. Food Hydrocolloids, 44, 208 219. doi:10.1016/j.foodhyd.2014.09.020

Pickardt, C., Neidhart, S., Griesbach, C., Dube, M., Knauf, U., Kammerer, D. R., \& Carle, R. (2009). Optimisation of mild-acidic protein extraction from defatted sunflower (Helianthus annuus L.) meal. Food Hydrocoinids, 23(7), 1966-1973. doi:10.1016/j.foodhyd.2009.02.001

Pickardt, C., Weisz, G. M., Eisner, P., Kammerer, D. R. Ne'dhart, S., \& Carle, R. (2011). Processing of low polyphenol protein isolates fru $\eta$ residues of sunflower seed oil production. Procedia Food Science, 1, 1417-14_``Ji:10.1016/j.profoo.2011.09.210

Pojić, M., Mišan, A., \& Tiwari, B. (2018). E - v innovative technologies for extraction of proteins for human consumption from ro"ewaole protein sources of plant origin. Trends in Food Science and Technology, 7. 9'-104. doi:10.1016/j.tifs.2018.03.010

Razumovsky, L., \& Damodaran, S. (1999). Surface Activity-Compressibility Relationship of Proteins at the Air-Water Interf ^c1. I angmuir, (15), 1392-1399.

Rodrigues, R. M., Avelar, Z., 'ı.nıe, A. A., Petersen, S. B., \& Pereira, R. N. (2020). Influence of moderate lectic fields in $\beta$-lactoglobulin thermal unfolding and interactions. Food Chc'nist, y, 304(August 2019). doi:10.1016/j.foodchem.2019.125442

Rodrigues, R. M., Fasoli 1, L H., Avelar, Z., Petersen, S. B., Vicente, A. A., \& Pereira, R. N. (2020). Effects of $m_{1}$ derate electric fields on cold-set gelation of whey proteins - From molecular interactions to functional properties. Food Hydrocolloids, 101(November 2019). doi:10.1016/j.foodhyd.2019.105505

Roebben, G., Ramirez-Garcia, S., Hackley, V. A., Roesslein, M., Klaessig, F., Kestens, V., Lynch, I., Garner, C. M., Rawle, A., Elder, A., Colvin, V. L., Kreyling, W., Krug, H. F., Lewicka, Z. A., McNeil, S., Nel, A., Patri, A., Wick, P., Wiesner, M., Xia, T., Oberdörster, G., \& Dawson, K. A. (2011). Interlaboratory comparison of size and surface charge measurements on nanoparticles prior to biological impact assessment. Journal of Nanoparticle Research, 13(7), 2675-2687. doi:10.1007/s11051-011-0423-y

Sá, A. G. A., Moreno, Y. M. F., \& Carciofi, B. A. M. (2020). Plant proteins as high-quality nutritional source for human diet. Trends in Food Science and Technology, 97(January), 
170-184. doi:10.1016/j.tifs.2020.01.011

Salgado, P. R., Molina Ortiz, S. E., Petruccelli, S., \& Mauri, A. N. (2011). Sunflower protein concentrates and isolates prepared from oil cakes have high water solubility and antioxidant capacity. JAOCS, Journal of the American Oil Chemists' Society, 88(3), 351-360. doi:10.1007/s11746-010-1673-z

Sanchez, A. C., \& Burgos, J. (1997). Gelation of Sunflower Globulin Hydrolysates: Rheological and Calorimetric Studies. Journal of Agricultural and Food Chemistry, (45), 2407-2412.

Shah, N. N., Umesh, K. V., \& Singhal, R. S. (2019). Hydrophobically modified pea proteins: Synthesis, characterization and evaluation as emulsifiers : $\eta$ eggless cake. Journal of Food Engineering, 255(October 2018), 15-23. doi:10.1C 16/j , foodeng.2019.03.005

Shiba, K., Niidome, T., Katoh, E., Xiang, H., Han, L., Mor, T., \& Katayama, Y. (2010). Polydispersity as a parameter for indicating the the r. al stability of proteins by dynamic light scattering. Analytical Sciences, 26(6), 659- ¿22 doi:10.2116/analsci.26.659

Singh, A., Orsat, V., \& Raghavan, V. (2013). Ooybean hydrophobic protein response to external electric field: A molecular mc eling approach. Biomolecules, 3(1), 168-179. doi:10.3390/biom3010168

Sosulski, F., \& Fleming, S. E. (19;7). Chemical, functional, and nutritional properties of sunflower protein products. Jo ir. rl of American Oil Chemistry Society, 54(2), A100A104.

Subaşı, B. G., Casanova, F., Cu anoglu, E., Ajalloueian, F., Sloth, J. J., \& Mohammadifar, M. A. (2020). Protein ext‘acts from de-oiled sunflower cake: Structural, physico-chemical and functional pro ertı 's after removal of phenolics. Food Bioscience, 38(100749). doi:10.1016/j.fbio.2 20.100749

Sun-Waterhouse, D., Zhao, M., \& Waterhouse, G. I. N. (2014). Protein Modification During Ingredient Preparation and Food Processing: Approaches to Improve Food Processability and Nutrition. Food and Bioprocess Technology, 7(7), 1853-1893. doi:10.1007/s11947014-1326-6

Tang, C. H., \& Sun, X. (2011). A comparative study of physicochemical and conformational properties in three vicilins from Phaseolus legumes: Implications for the structurefunction relationship. Food Hydrocolloids, 25(3), 315-324. doi:10.1016/j.foodhyd.2010.06.009

Tapal, A., \& Tiku, P. K. (2018). Nutritional and nutraceutical improvement by enzymatic modification of food proteins. Enzymes in Food Biotechnology: Production, 
Applications, and Future Prospects, 471-481. doi:10.1016/B978-0-12-813280-7.00027$\mathrm{X}$

Tomczyńska-Mleko, M., Kamysz, E., Sikorska, E., Puchalski, C., Mleko, S., Ozimek, L., ... Wesołowska-Trojanowska, M. (2018). Changes of secondary structure and surface tension of whey protein isolate dispersions upon $\mathrm{pH}$ and temperature. Czech Journal of Food Sciences, 32(No. 1), 82-89. doi:10.17221/326/2012-cjfs

Vivian, J. T., \& Callis, P. R. (2001). Mechanisms of tryptophan fluorescence shifts in proteins. Biophysical Journal, 80(5), 2093-2109. doi:10.1016/S0006-3495(01)76183-8

Wang, Chen, Jiang, L., Wei, D., Li, Y., Sui, X., Wang, Z., \& Li, D. (2011). Effect of secondary structure determined by FTIR spectra on surfa protein isolate. Procedia Engineering, 15, 4819-4827. d i i:1c , 1016/j.proeng.2011.08.900

Wang, Chunyang, Ma, Y., Liu, B., Kang, Z., Geng, S., V ang J., Wei, L., \& Ma, H. (2019). Effects of dynamic ultra-high pressure homogeniza: in on the structure and functional properties of casein. International Journal of $A_{\delta}$ nir altural and Biological Engineering, 12(1), 229-234. doi:10.25165/j.ijabe.20191 _u 3015

Wang, Z., Li, Y., Jiang, L., Qi, B., \& Zhc", L. (2014). Relationship between secondary structure and surface hydrophob itv of soybean protein isolate subjected to heat treatment. Journal of Chemistry, ?014. doi:10.1155/2014/475389

Weisz, G. M., Schneider, L., Sch wisogert, U., Kammerer, D. R., \& Carle, R. (2010). Sustainable sunflower processing - I. Development of a process for the adsorptive decolorization of sunflov ${ }^{2}$ [I Ielianthus annuus L.] protein extracts. Innovative Food Science and Emerging Tect, lologies, 11(4), 733-741. doi:10.1016/j.ifset.2010.05.005

Xiong, T., Xiong, W., (re, 1 1., Xia, J., Li, B., \& Chen, Y. (2018). Effect of high intensity ultrasound on struc re and foaming properties of pea protein isolate. Food Research International, 109, 260-267. doi:10.1016/j.foodres.2018.04.044

Yu, Z. L., Zeng, W. C., Zhang, W. H., Liao, X. P., \& Shi, B. (2014). Effect of ultrasound on the activity and conformation of $\alpha$-amylase, papain and pepsin. Ultrasonics Sonochemistry, 21(3), 930-936. doi:10.1016/j.ultsonch.2013.11.002 


\section{Author Statement}

Büşra Gültekin Subaşı and Mastaneh Jahromi: Conceptualization, Methodology, Validation, Formal analysis, Data curation, Writing - Original Draft, Writing - Review \& Editing. Federico Casanova and Fatemeh Ajalloueian: Conceptualization, Data Curation, Writing - Original Draft, Writing - Review \& Editing, Visualization. Esra Capanoglu and Mohammad Amin Mohammadifar: Writing - Review \& Editing, Visualization, Supervision, Project administration and Funding acquisition. 


\section{Highlights}

- Non-thermal effect of moderate electric field on protein structure was investigated.

- Treated SPI and CAS present lower air/water surface activity and higher hydrophilicity.

- Smaller sized particle distributions were observed for treated proteins.

- Lower denaturation temperature and enthalpies were observed for treated protein. 


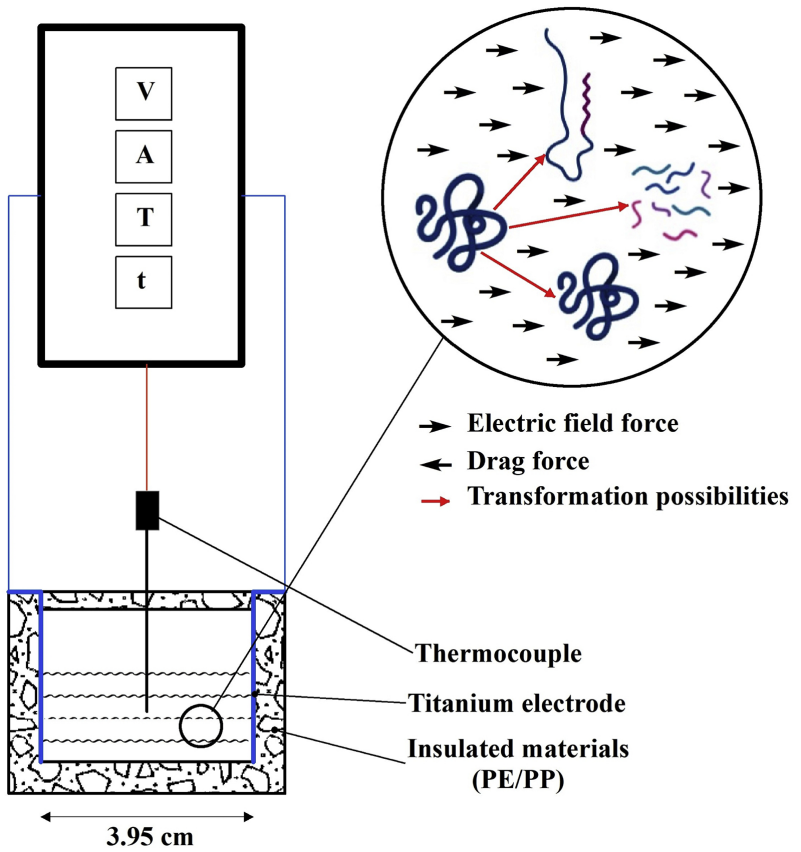

Figure 1 
A
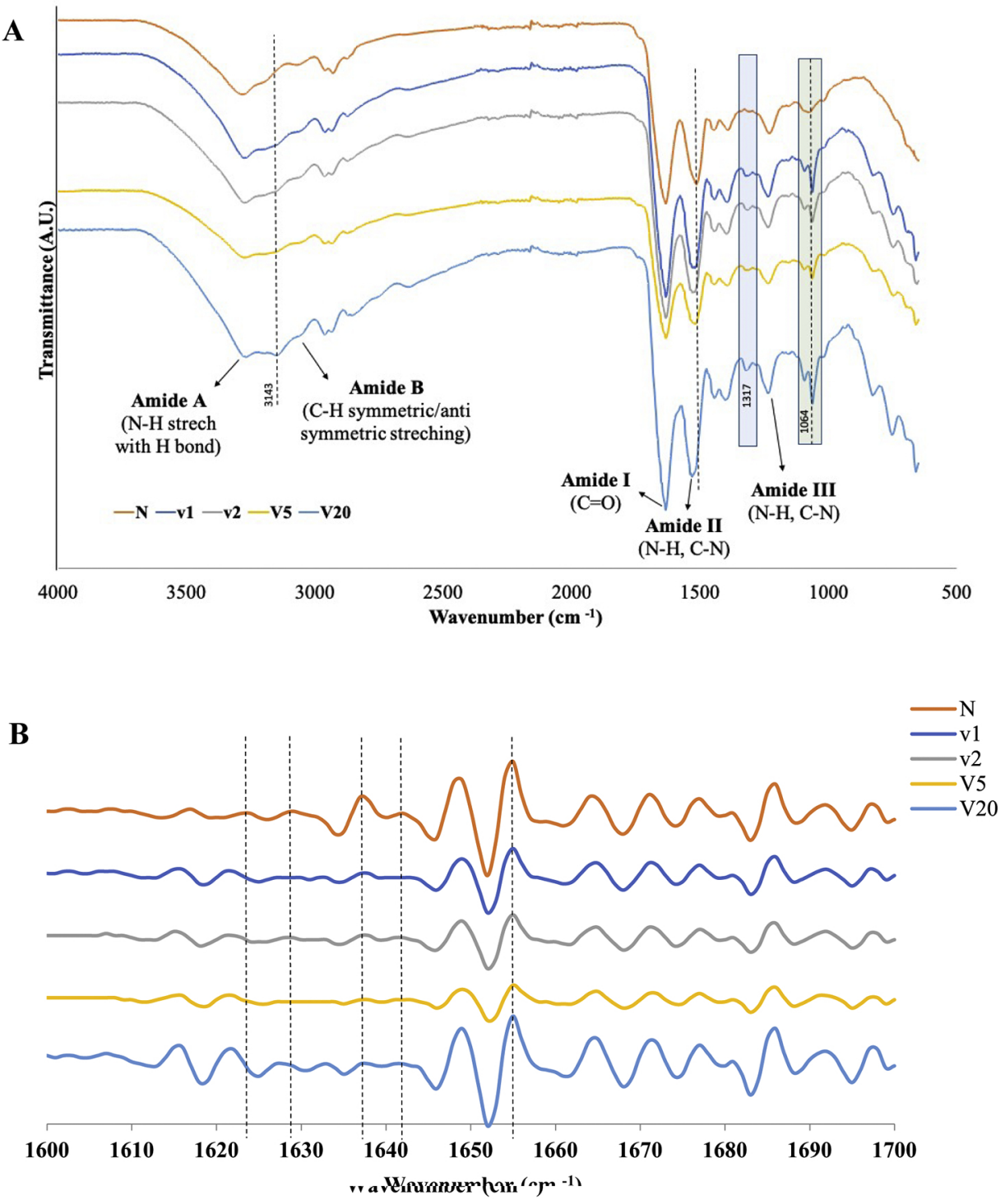

Figure 2 

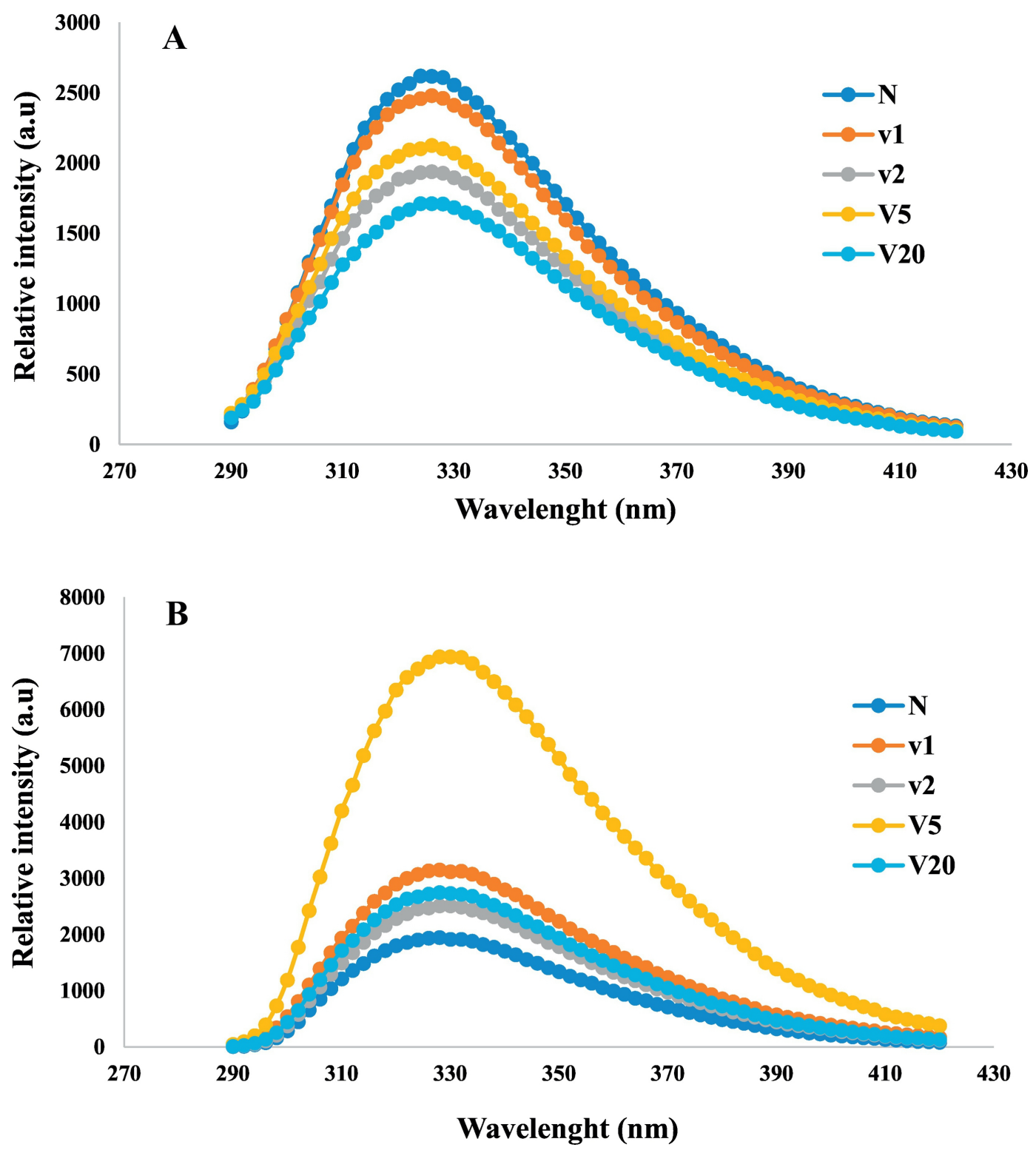

Figure 3 